\title{
QUEEN'S
UNIVERSITY
BELFAST
}

\section{Preparation of Cytocompatible ITO Neuroelectrodes with Enhanced Electrochemical Characteristics Using a Facile Anodic Oxidation} \section{Process}

Vallejo-Giraldo, C., Pampaloni, N. P., Pallipurath, A. R., Mokarian-Tabari, P., O'Connell, J., Holmes, J. D., Trotier, A., Krukiewicz, K., Orpella-Aceret, G., Pugliese, E., Ballerini, L., Kilcoyne, M., Dowd, E., Quinlan, L. R., Pandit, A., Kavanagh, P., \& Biggs, M. J. P. (2017). Preparation of Cytocompatible ITO Neuroelectrodes with Enhanced Electrochemical Characteristics Using a Facile Anodic Oxidation Process. Advanced Functional Materials, 28(12), [1605035]. https://doi.org/10.1002/adfm.201605035

Published in:

Advanced Functional Materials

Document Version:

Peer reviewed version

Queen's University Belfast - Research Portal:

Link to publication record in Queen's University Belfast Research Portal

Publisher rights

(c) 2017 Wiley-VCH Verlag GmbH \& Co.

This work is made available online in accordance with the publisher's policies. Please refer to any applicable terms of use of the publisher.

\section{General rights}

Copyright for the publications made accessible via the Queen's University Belfast Research Portal is retained by the author(s) and / or other copyright owners and it is a condition of accessing these publications that users recognise and abide by the legal requirements associated with these rights.

\section{Take down policy}

The Research Portal is Queen's institutional repository that provides access to Queen's research output. Every effort has been made to ensure that content in the Research Portal does not infringe any person's rights, or applicable UK laws. If you discover content in the Research Portal that you believe breaches copyright or violates any law, please contact openaccess@qub.ac.uk. 


\section{WILEY-VCH}

DOI: 10.1002/ ((please add manuscript number))

Article type: Full Paper

\section{Preparation of Cytocompatible ITO Neuroelectrodes with Enhanced Electrochemical Characteristics Using a Facile Anodic Oxidation Process.}

Catalina Vallejo-Giraldo, Anuradha R. Pallipurath, Niccolò Paolo Pampaloni, John O'Connell, Gemma Orpella-Aceret, Eugenia Pugliese, Alexandre Trotier, Parvaneh Mokarian-Tabari, Justin D. Holmes, Laura Ballerini, Eilís Dowd, Abhay Pandit, Paul Kavanagh* and Manus Jonathan Paul Biggs*

MSc Catalina Vallejo-Giraldo, MSc Gemma Orpella-Aceret, MSc Eugenia Pugliese, MSc Alexandre Trotier, Prof. Abhay Pandit, Dr Manus Jonathan Paul Biggs

CÚRAM - Centre for Research in Medical Devices - Galway, Biosciences Research Building, 118 Corrib Village, Newcastle, Galway, Ireland

E-mail: manus.biggs@nuigalway.ie

MSc Niccolò Paolo Pampaloni, Prof. Laura Ballerini

Scuola Internazionale Superiore di Studi Avanzati (SISSA), Via Bonomea, 265, 34136,Trieste, Italy

MSc John O’Connell, Dr Parvaneh Mokarian-Tabari, Prof. Justin D. Holmes,

Department of Chemistry, University College Cork, Cork, Ireland

Tyndall National Institute, University College Cork, Cork, Ireland

Centre for Research on Adaptive Nanostructures and Nanodevices (CRANN) and AMBER

Centre, Trinity College Dublin, Dublin 2, Ireland.

Dr Eilís Dowd

Department of Pharmacology, Physiology, NUI Galway, University Rd, Galway, Ireland

Dr Paul Kavanagh, Dr Anuradha Radhakrishnan Pallipurath

School of Chemistry, NUI Galway, University Rd, Galway, Ireland

E-mail: paul.kavanagh@ @uigalway.ie

Keywords: indium-tin-oxide, cytocompatibility, neural interfaces, functionalization, electrodes

Physicochemical modification of implantable electrode systems is recognized as a viable strategy to enhance tissue/electrode integration and electrode performance in situ. In this work, a bench-top electrochemical process to formulate anodized ITO films with altered roughness, thickness and conducting profiles was explored. In addition, the influence of these anodized films on SH-5YSY cell proliferation, viability and focal adhesion reinforcement indicated that anodized ITO film cytocompatibility can be altered by varying the anodization current density. Furthermore, an ITO anodized films formed with a current density of $0.4 \mathrm{~mA} \mathrm{~cm}{ }^{-2}$ showed important primary neural cell survival and promotion of neural network activity. 


\section{WILEY-VCH}

\section{Introduction}

The modification of implantable electrodes for neural stimulation and recording through electrochemical, biochemical and topographical functionalization has been a major focus of neural engineering in the past five years. ${ }^{[1,2]}$ A common occurrence following electrode implantation is the formation of a glial scar or reactive gliosis. This encapsulating scar forms at the electrode-tissue interface and accelerates neural loss, increases electrical signal impedance and thereby compromises the efficiency of the stimulating/recording system. ${ }^{[1]}$ Biomimetic interfaces with multiple functionalities that facilitate stable charge transfer over extended times in vivo while promoting enhanced cell interaction, selection and attachment are critical in chronic neuroelectrode functionality and the development of advanced brain/machine interfaces. Ongoing strategies have focused on morphological and biochemical modification of the electrode-tissue interface to reduce tissue damage and promote electrode integration through miniaturization and the localized delivery of anti-fibrotic or neurotropic chemistries. ${ }^{[3]}$ Chemically inert conductors such as gold, platinum and iridium as well as semiconductors such as silicon have been widely employed as electrode systems in both clinical and research settings and have been found to perform well under non-chronic settings ${ }^{[4,5]}$ Recently, non-metallic electrically conducting biomaterials including inherently conducting polymers and polymer composites have been explored as neuroelectrode alternatives in an effort to promote chronic functionality and enhanced biocompatibility. ${ }^{[6,7]}$ In the field of conductive metal oxide electronics, indium-tin oxide (ITO) is one of the most intensively investigated materials because its relatively low electrical resistivity, its transparency and its thermal stability, makes it well-suited for use as an electrode and a sensor material. ${ }^{[8]}$ Specifically, ITO films have been employed successfully in the fabrication of optoelectronic and electrochromic devices, ${ }^{[9]}$ electroluminescent devices, ${ }^{[10]}$ photovoltaic cells, ${ }^{[11]}$ and sensors. ${ }^{[12]}$ Recent studies indicate the potential of ITO derived electrically

conducting systems for biological applications. ${ }^{[13-19]}$ Indeed, Selvakumaran et al. ${ }^{[20]}$ 


\section{WILEY-VCH}

demonstrated that ITO can be a useful material for obtaining physiological measurements in vitro. Their findings show that ITO offered a compromise between promoting cell growth while adsorbing significantly less protein than a titanium substrate. ${ }^{[16][21]}$

Recently, Tanamoto and colleagues ${ }^{[15]}$ have developed an ITO glass electrode device to stimulate cells without a counter electrode. The device can uniformly stimulate multiple cells with potential in vivo implantable applications. Additionally, it has been shown that ITO can be physically and chemically modified to locally tailor its associated electrical, optical and material properties, ${ }^{[22]}$ increasing its potential for neuroelectrode applications. Surface treatments such as acid etching, ${ }^{[23]}$ and layer-by-layer assembly ${ }^{[24]}$ have been used to modulate and alter the performance of ITO for commercial applications.

Electrochemical activation or passivation via the anodic oxidation (anodization process) ${ }^{[25,26]}$ is widely used in biomedical engineering to grow metal oxide dielectrics for electrical devices $^{[27,28]}$ and to obtain protective and decorative films on metallic surfaces to increase corrosion resistance. ${ }^{[29]}$ The experimental conditions, i.e galvanostatic or potentiostatic anodization deposition, electrolyte composition, and deposition time facilitate the oxidation of ions at the substrate-solution interface to produce thin-film coatings. ${ }^{[30]}$ Importantly, several research groups have demonstrated that the anodic oxidation technique can be employed in conjunction with mask strategies for the generation of biologically passive layers or nanofeatures on titanium ${ }^{[31][32-36]}$ and alumina ${ }^{[37][38]}$ by which to improve cell adhesion and implant interface interaction.

Although anodization processes have been widely used in biomedical engineering for the functionalization of titanium and aluminium implantable materials, surface modification of ITO via anodization has not yet been explored as a method to enhance cytocompatibility, cell adhesion and functionality in implantable systems. Furthermore, the effects of ITO anodization on film electrochemical impedance and topography remain unknown. 


\section{WILEY-VCH}

In this study an ITO anodization is explored as a functionalization approach for the generation of cytocompatible thin-film electrodes for potential neural applications for the first time.

In this work, anodized ITO thin-films were formulated through a facile electrochemical process employing the application of different current densities and the physical, chemical, electrochemical and cytocompatibility effects were explored. Our results elucidate important material effects with regard to anodization current densities on ITO film surface morphology, electrochemistry, and cytocompatibility for the generation of neural interfaces with superior electrical and biological characteristics.

\section{Results and Discussion}

When subjected to anodic ${ }^{[39-43]}$ and cathodic ${ }^{[42-45]}$ polarization, ITO electrodes can undergo changes in chemical composition, ${ }^{[39-45]}$ surface morphology ${ }^{[39,40,42-45]}$ conductivity ${ }^{[39,40,42-45]}$ and optical transparency ${ }^{[41-45]}$. Such effects are largely influenced by i) the electrochemical parameters selected for electrode polarization and ii) composition of the electrolyte solution. ${ }^{[39-45]}$ For example, polarization at high positive potentials (> $1.5 \mathrm{~V}$ vs. SCE) in aqueous electrolyte can cause substantial structural changes to the ITO electrode.[40] Similarly, polarization in strong acid $\left(1 \mathrm{M} \mathrm{HNO}_{3}\right)$ or strong base $(1 \mathrm{M} \mathrm{NaOH})$ can result in a dramatic reduction in electrochemical activity, electrical conductivity and optical transparency of the ITO electrode. ${ }^{[45]}$ Such effects are normally attributed to structural and/or chemical changes within the ITO film induced by the polarization process, ${ }^{[39,40]}$ which, under harsh electrochemical conditions, may result in partial or complete dissolution of ITO coating. ${ }^{[39-43]}$

Here, we report a novel method for the facile fabrication of bioactive ITO substrates with enhanced electrochemical properties as neural interfaces. Due to the detrimental effects on ITO films resulting from anodization in harsh chemical conditions detailed above, we chose to perform the anodization process in a relatively mild electrolyte consisting of $0.01 \mathrm{M}$ phosphate-buffered saline solution (PBS) and $10 \mu \mathrm{M}$ PSS. Constant current densities of 0.4 


\section{WILEY-VCH}

$\mathrm{mA} \mathrm{cm}{ }^{-2}, 4 \mathrm{~mA} \mathrm{~cm}^{-2}$ and $43 \mathrm{~mA} \mathrm{~cm}{ }^{-2}$ applied for 450 seconds were used to prepare modified ITO films through anodization in this electrolyte.

The following sections describe the physical, chemical, electrochemical, and biocompatibility properties of resulting films.

\subsection{Physical Characterization of Anodized ITO Films}

Systematic studies of thin-film ITO post-deposition processing in optoelectronic device fabrication have focused on the processing effects on surface roughness and on the generation of defined nanostructures. To a great extent, techniques such as chemical-bath deposition $(\mathrm{CBD})^{[46]}$ and thermal annealing ${ }^{[47]}$ respectively have been utilized to modify film physicochemical properties with resulting films showing considerable morphological changes which translate into the optical transmittance and electrical conductivity. While a number of studies have explored anodization processes to produce micro-porous titanium oxide films on implant surfaces for orthopedic applications, ${ }^{[48]}$ the impact of anodization on the physical properties of ITO substrates for neural interfaces has not been investigated thus far.

Figure 1A shows representative SEM images of anodized ITO films using $0.4 \mathrm{~mA} \mathrm{~cm} \mathrm{~cm}^{-2}, 4$ $\mathrm{mA} \mathrm{cm}{ }^{-2}$ and $43 \mathrm{~mA} \mathrm{~cm}^{-2}$ current densities over a constant time of 450 seconds, and pristine ITO coated glass as a control substrate. It is interesting to note that pristine ITO films possess a surface morphology composed of a random assembly of nanoparticles that is developed into a nanoparticulate/granular morphology in films anodized under our experimental conditions. The quantification of the degree of nodularity revealed significant differences in nodule diameter with different deposition current densities. Film growth using higher current densities yielded less-dense, non-uniform films relative to anodized films formed with lower current densities. ${ }^{[49]}$

Experimentally, pristine ITO films reported a mean particle size of $86 \mathrm{~nm}$, films formed with $0.4 \mathrm{~mA} \mathrm{~cm}{ }^{-2}$ were associated with a mean particle size of $89 \mathrm{~nm}$; and mean particle diameters of $152 \mathrm{~nm}$ and $112 \mathrm{~nm}$ were observed in films formed using $4 \mathrm{~mA} \mathrm{~cm}{ }^{-2}$ and $43 \mathrm{~mA} \mathrm{~cm} \mathrm{~cm}^{-2}$ 


\section{WILEY-VCH}

current densities respectively. At $0.4 \mathrm{~mA} \mathrm{~cm}^{-2}$, the observed nodular distribution was uniform and compact. However, at $4 \mathrm{~mA} \mathrm{~cm}{ }^{-2}$ and $43 \mathrm{~mA} \mathrm{~cm}^{-2}$ current densities, a more clustered grain-like structure and non-homogeneous distribution was evident. This suggests that current deposition strongly affects the processes of surface diffusion of atoms, nucleation and coalescence of the film growth resulting in different nucleation densities at the surface. ${ }^{[50,51]}$ Even though low deposition current densities can be associated with low nuclei density and therefore poor film formation, it can be noted that by the specific use of a current density of $0.4 \mathrm{~mA} \mathrm{~cm} \mathrm{~cm}^{-2}$, ITO oxidized films were uniformly extended. Furthermore, the nanoscale morphology correlated with an increase in the measured surface roughness $\left(R_{a}\right)$ of the anodized films relative to pristine ITO films and all anodization processes resulted in significant increases in $R_{a}$ as a function of current density (Figure 1B). Films formed with current densities of $0.4 \mathrm{~mA} \mathrm{~cm}{ }^{-2}$ exhibited an average roughness of $19 \mathrm{~nm}$ over $10 \mu \mathrm{m}^{2}$, and an average roughness of $81 \mathrm{~nm}$ and $61 \mathrm{~nm}$ when formed at $4 \mathrm{~mA} \mathrm{~cm}{ }^{-2}$ and $43 \mathrm{~mA} \mathrm{~cm} \mathrm{~cm}^{-2}$ respectively. Conversely, pristine ITO films possessed a $R_{a}$ of $1 \mathrm{~nm}$ over $10 \mu \mathrm{m}^{2}$. A similar trend was also observed for mean nodule diameter, which increased from $89 \mathrm{~nm}$ in current densities of $0.4 \mathrm{~mA} \mathrm{~cm}^{-2}$ to $152 \mathrm{~nm}$ and $112 \mathrm{~nm}$ in films formed with current densities of 4 $\mathrm{mA} \mathrm{cm}{ }^{-2}$ and $43 \mathrm{~mA} \mathrm{~cm}^{-2}$ respectively (Table 1).

Similarly, an abrupt increase in film thickness was observed in films formed with current densities of $4 \mathrm{~mA} \mathrm{~cm}^{-2}$ and $43 \mathrm{~mA} \mathrm{~cm}^{-2}$ indicating that the maximum rate of anodization deposition is limited by the electrolyte diffusion rate. ${ }^{[4]}$ The limiting current density for approximately 100 per cent efficiency of film deposition can be determined theoretically by calculating the maximum rate at which the ions diffuse to the cathode. Our data (Table 1) proposes that at $4 \mathrm{~mA} \mathrm{~cm}^{-2}$ (under our experimental conditions), the threshold for the limiting current density may already met ${ }^{[33,49]}$ and the observed non-linear increases in particle size, film roughness and the plateau in film thickness, could be indications that films formed using a current density of $4 \mathrm{~mA} \mathrm{~cm}^{-2}$ under our experimental conditions, are associated with a 


\section{WILEY-VCH}

decrease in film growth efficiency. Therefore, it can be assumed that between $4 \mathrm{~mA} \mathrm{~cm}^{-2}$ and $43 \mathrm{~mA} \mathrm{~cm}{ }^{-2}$ can be found the diffusion limiting current density for ITO anodization, and that the diffusion kinetics of oxygen and hydrogen at the cathode are insufficient, causing reactions at the anode to stop to conserve electrons.

Similarly, this transition in film thickness was also represented in the visual colour of the films which changed from a translucent blue-grey to an opaque dark grey (Figure S2). It could be anticipated, according to Drude model, ${ }^{[52]}$ that the changes observed in film morphology derived from the differences in film growth imposed by the current densities, would impact the refractive index of films. Optical transmission spectra of the pristine ITO coated glass and the anodized ITO films formed at $0.4 \mathrm{~mA} \mathrm{~cm}-2,4 \mathrm{~mA} \mathrm{~cm}{ }^{-2}$ and $43 \mathrm{~mA} \mathrm{~cm}-2$ current densities were performed to quantify film transparency (Figure S3). The observed trend in optical transmittance of the anodized ITO films formed at higher current densities (4 $\mathrm{mA} \mathrm{cm}{ }^{-2}$ and $43 \mathrm{~mA} \mathrm{~cm}^{-2}$ ) reflects scattering losses as predicted by the effects of film roughness. ${ }^{[53]}$ The aforementioned faster growth observed in films formed at $4 \mathrm{~mA} \mathrm{~cm}^{-2}$ resulted in the decrease in transmittance of these films.

\subsection{Chemical characterization}

In Table 2 the XPS survey with the elemental composition of pristine ITO and anodized ITO films using $0.4 \mathrm{~mA} \mathrm{~cm}^{-2}, 4 \mathrm{~mA} \mathrm{~cm}^{-2}$ and $43 \mathrm{~mA} \mathrm{~cm}^{-2}$ is reported. The XPS survey spectrum of pristine ITO revealed the presence of prominent In, Sn and O peaks. The atomic percentage for $\mathrm{C}$ is also relatively high showing a large presence of atmospheric $\mathrm{C}$ on the film surface. Similarly, low-current density anodized samples consisted primarily of In, Sn and O. The O concentration was observed to increase significantly in anodized ITO films, increasing from $42 \%$ O1s atomic $\%$ in pristine ITO films to $49.81 \%$ in anodized films formed with current densities of $43 \mathrm{~mA} \mathrm{~cm}{ }^{-2}$. Conversely, the $\mathrm{Sn}$ atomic \% is reduced in anodized ITO films relative to pristine films, which is reportedly due to the leaching of Sn into the electrolyte during the anodization process. ${ }^{[40]}$ 


\section{WILEY-VCH}

\subsection{Electrochemical Characterization}

Figure 2A shows cyclic voltammograms for each of the ITO films in $50 \mathrm{mM}$ phosphate buffer before and after anodization. Surface charge density was approximated through integration of the charge passed within the cathodic region of voltammetric scans, corresponding to charge densities of $49 \mu \mathrm{C} \mathrm{cm}^{-2}, 341 \mu \mathrm{C} \mathrm{cm}^{-2}, 15 \mu \mathrm{C} \mathrm{cm}^{-2}$ and $15 \mu \mathrm{C} \mathrm{cm}{ }^{-2}$ for pristine ITO films and films subjected to anodization at $0.4 \mathrm{~mA} \mathrm{~cm}^{-2}, 4 \mathrm{~mA} \mathrm{~cm}-2$ and $43 \mathrm{~mA}$ $\mathrm{cm}^{-2}$ current densities respectively (Table 3). A large increase in charge density was observed in ITO films subjected to anodization at $0.4 \mathrm{~mA} \mathrm{~cm}-2$, by almost one order of magnitude, compared to pristine ITO films. This is likely due to the greater surface coverage as indicted by SEM and AFM analysis. Interestingly, a three-fold reduction in charge density was observed for ITO films subjected to anodization at current densities of $4 \mathrm{~mA} \mathrm{~cm}{ }^{-2}$ and $43 \mathrm{~mA}$ $\mathrm{cm}^{-2}$ compared to the pristine ITO films (Figure 2A) despite increased surface roughness. No appreciable difference in charge density was observed in any of the ITO substrates when tested in physiological-like saline solution ${ }^{[54]}$ compared to $50 \mathrm{mM}$ phosphate buffer solution. Comparative electrochemical impedance profiles for films are shown in the Bode diagram (Figure 2C). Within frequency ranges of $10^{-1}-10^{4} \mathrm{~Hz}$, ITO anodized films formed at a current density of $0.4 \mathrm{~mA} \mathrm{~cm}{ }^{-2}$ displayed the lowest impedance profiles, moderately lower than that recorded for the pristine ITO films and close to the impedance observed for gold coated glass films. This indicates that changes in chemical composition and/or morphology induced by the $0.4 \mathrm{~cm}^{-2}$ current density anodization process do not appear to diminish the conductive properties of the ITO electrode. This is significant as alternative electrochemical treatments have been shown to greatly decrease the conductivity of ITO electrodes. ${ }^{[40,42-45]}$ However, an increase in impedance of one order of magnitude was observed for films formed at high current densities $\left(4 \mathrm{~mA} \mathrm{~cm}{ }^{-2}\right.$ and $\left.43 \mathrm{~mA} \mathrm{~cm}^{-2}\right)$, revealing an inverse relationship between electrical conductivity and the anodization current density applied. 


\section{WILEY-VCH}

To further evaluate the electrochemical characteristics of the ITO anodized films, a ruthenium hexamine $\left(\left[\mathrm{Ru}\left(\mathrm{NH}_{3}\right)_{6}\right]^{3+}\right)$ redox probe was employed to examine faradaic redox response within a biologically relevant potential range ( -0.4 to $+0.2 \mathrm{~V}$ vs. $\mathrm{Ag} / \mathrm{AgCl})$ (Figure $2 \mathrm{~B})$. With pristine ITO films, $\left[\mathrm{Ru}\left(\mathrm{NH}_{3}\right)_{6}\right]^{3+}$ undergoes a one electron redox reaction (redox potential $\left(\mathrm{E}^{\mathrm{o}^{\prime}}\right)=-0.13 \mathrm{~V}$ vs. $\left.\mathrm{Ag} / \mathrm{AgCl}\right)$, yielding an anodic peak current $\left(\mathrm{i}_{\mathrm{pa}}\right)$ of $0.62 \mathrm{~mA} \mathrm{~cm}{ }^{-2}$. A slight increase of $i_{p a}$ is observed with ITO films formed through anodization at $0.4 \mathrm{~mA} \mathrm{~cm}{ }^{-2}$, possibly due to the increased surface roughness. This shows that although the non-faradaic charge density is greater with these films, the increased surface roughness does not translate into a greater electrochemically active surface area compared to the relatively smooth nonanodized ITO film. Kraft et. al. ${ }^{[40]}$ observed a similar response using $\left[\mathrm{Fe}(\mathrm{CN})_{6}\right]^{3-}$ as a redox probe, where non-faradaic current (charge density) increased after ITO electrode anodization while faradaic current remained essentially constant. A large decrease of $i_{p a}$ is evident in ITO films subjected to anodization with current densities greater than $0.4 \mathrm{~mA} \mathrm{~cm}{ }^{-2}$, accompanied by a slight decrease in $\mathrm{E}^{\mathrm{o}^{\prime}}$ of $c a .10 \mathrm{mV}$ for the $\mathrm{Ru}^{3+/ 2+}$ redox couple (Table 3). The difference in $\mathrm{E}^{\mathrm{o}^{\prime}}$ may result from variation in chemisoption sites within the electrode film which can influence redox probe stability. ${ }^{[5]}$ The voltammetric response observed for ITO films anodized at $43 \mathrm{~mA} \mathrm{~cm}^{-2}$ is characteristic of a highly resistive surface with no evidence of heterogeneous electron transfer between the electrode and the redox probe. ${ }^{[56]}$

Scan rate studies (Figure S4) revealed a linear dependence of ipa vs. $v^{1 / 2}(v=$ scan rate) for all ITO films (with the exception of ITO anodized films formed with current densities of $43 \mathrm{~mA}$ $\mathrm{cm}^{-2}$ ), indicative of a semi-infinite planar diffusional response described by the RandlesSevcik equation. ${ }^{[57]}$ Diffusion coefficients $\left(D_{0}\right)$, evaluated from the linear portion of $i_{p a} v s . v^{1 / 2}$, are shown in Table 3. $\mathrm{D}_{\mathrm{o}}$ values in the order of $10^{-6} \mathrm{~cm} \mathrm{~s}^{-1}$ were calculated for $\left[\mathrm{Ru}\left(\mathrm{NH}_{3}\right)_{6}\right]^{3+}$ at both pristine ITO and ITO films formed through anodization at $0.4 \mathrm{~mA} \mathrm{~cm}-2$ in a phosphate buffer. Again, a decrease of $D_{0}$, by approximately three orders of magnitude, is evident for ITO films subjected to anodization with current densities of $4 \mathrm{~mA} \mathrm{~cm}{ }^{-2}$ and $43 \mathrm{~mA} \mathrm{~cm}{ }^{-2}$, 


\section{WILEY-VCH}

further corroborating the insulating nature of films prepared at anodizing current densities greater than $0.4 \mathrm{~mA} \mathrm{~cm}^{-2}$.

Interestingly, the presence of PSS ionomer was critical for anodization process and ITO thinfilms subjected to anodic oxidation under ambient conditions in a $0.01 \mathrm{M}$ phosphate-buffered saline solution were associated with a linear increase in impedance profile as a function of current density (Figure S5).

\subsection{Biological Characterization}

Nanoscale signaling modality has been shown to have a profound effect on cell viability, proliferation and on cell attachment in the material's space.$^{[58-60]}$ Because the application of different current densities for the anodization of ITO films resulted in defined natural occurring nanoscale morphological changes, the cellular interfacial response has been analyzed based on the resulting roughness profiles of these surfaces. With this in mind, the films formed at $0.4 \mathrm{~mA} \mathrm{~cm}{ }^{-2}, 4 \mathrm{~mA} \mathrm{~cm}^{-2}$ and $43 \mathrm{~mA} \mathrm{~cm}^{-2}$ current densities, which in order exhibit an average of roughness of $19 \mathrm{~nm}, 81 \mathrm{~nm}$ and $61 \mathrm{~nm}$ respectively, were studied using human neuroblastoma SH-SY5Y cells. These were then compared to pristine ITO coated glass with an experimental average roughness of $1 \mathrm{~nm}$ (Figure 3A). After a period of one, seven and fourteen days, cells were stained with calcein (live) and ethidium homodimer (dead) to establish cell viability. All films were non-toxic to SH-SY5Y cells relative to cells cultured on pristine ITO coated glass. Significant differences were observed at day fourteen with respect to cell viability. Cells grown on films with the lowest roughness profile which resulted from films formed at the lowest current density $0.4 \mathrm{~mA} \mathrm{~cm}{ }^{-2} ;\left(\mathrm{R}_{\mathrm{a}}=19 \mathrm{~nm}\right.$ over 10 $\mu \mathrm{m}^{2}$ ) maintained $86 \%$ viability relative to the other anodized films (Figure 3B). Similarly, when analyzed with Alamar Blue assay by 24h (Figure 3C), the SH-SY5Y population cultured on anodized ITO films was comparable to cells cultured on control pristine ITO coated glass. While by days seven cells cultured on all experimental anodized films demonstrated a marked decreasing trend in metabolic activity, the anodized films with $19 \mathrm{~nm}$ 


\section{WILEY-VCH}

roughness (the lowest roughness profile corresponding to films formed at $0.4 \mathrm{~mA} \mathrm{~cm}^{-2}$ current density) showed an overall significant higher metabolic activity (87\% and $78 \%$ respectively) compared to $61 \mathrm{~nm}$ and 81 film's roughness profiles and pristine ITO control substrates. The anodized ITO film with $81 \mathrm{~nm}$ roughness, the highest roughness profile, showed a significant decrease in metabolic activity relative to cells cultured on control ITO coated glass and on anodized films with $19 \mathrm{~nm}$ roughness; the lowest roughness. These results are similar to those of Fan et al. ${ }^{[61]}$ In their work, they have reported on the cell proliferation of neural cells cultured on silicon wafers possessing different levels of surface roughness. Fan et al. concluded that the $\mathrm{Si}$ wafers with surface $\mathrm{R}_{\mathrm{a}}$ ranging from 20 to $50 \mathrm{~nm}$ promoted a much higher cell proliferation. On surfaces with $\mathrm{R}_{\mathrm{a}}$ less than about $10 \mathrm{~nm}$ and on rough surfaces with $R_{a}$ above $70 \mathrm{~nm}$, cell metabolic activity was much lower. It is noteworthy that even though cell proliferation and viability depend on cell type and substrate composition, it is apparent that neurons do not readily attach on very smooth or rough surfaces. ${ }^{[62]}$

Furthermore, tissues can be described as complex nanoscale composites that impact morphological and mechanical features to the resident cellular constituents. Previous studies show that nanotopography influences cellular function and focal adhesion (FA) formation in vitro ${ }^{[58,63]}$ and may be employed to modulate the dynamic interface between materials and cell/tissues. With an awareness of this, cell attachment to the anodized ITO films was quantified through immunofluorescent labelling of the FA associated protein paxillin ${ }^{[64]}$ (Figure 4A-D). At day one, cells cultured on all experimental films and control pristine ITO glass were associated with an overall average of approximately fourteen focal adhesions per cell. By day seven, SH-SY5Y cells cultured on pristine ITO control presented a significant increase in FA numbers per cell, an average of 25 focal adhesions per cell, compared to all the experimental anodized ITO films with an average number of seventeen FAs per cell. Interestingly, trends in FA numbers were reversed in cells cultured on the pristine ITO control group by day seven which demonstrated a significant reduction in FA number by day fourteen 


\section{WILEY-VCH}

(Figure 4E). Conversely, previous studies have reported a disruption to cell adhesion by nanorough surfaces with similar roughness profiles ${ }^{[58,65]}$ and a decrease in cell viability; however, FA quantification was not performed in these studies. Specifically, it was noted by Brunetti et al ${ }^{[58]}$ that cellular adhesion was significantly increased on regions of low (smooth) roughness.

Similarly, FA length was observed to be significantly greater in cells cultured on pristine ITO control substrates relative to cells cultured on anodized films by day seven. By day fourteen, the FA length in the experimental anodized films with the lowest and highest roughness profiles (19 $\mathrm{nm}$ and $81 \mathrm{~nm}$ ) was significantly higher than the length of FAs in cells cultured on pristine ITO control substrates (Figure 4F). A significant reduction in FA length was noted however in cells cultured on $R_{a}$ film roughness of $61 \mathrm{~nm}$ over $10 \mu \mathrm{m}^{2}$. Significantly, these were the films formed with the highest current density $\left(43 \mathrm{~mA} \mathrm{~cm}{ }^{-2}\right)$. This reduction in FA reinforcement may be related to the particle diameter and nanofeatures with lateral dimensions of approx. $100 \mathrm{~nm}$ that have been shown to be disruptive to integrin clustering ${ }^{[63][66]}$, an effect which is lost by reducing or increasing the feature dimensions, an effect also demonstrated here.

In addition, to gain further insight into cell adhesion, the length of the FAs was sub-grouped in focal complexes (FXs) measuring $<1 \mu \mathrm{m}$ in length and FAs proper, measuring between 1-5 $\mu \mathrm{m}$. FXs were most abundant in cells cultured on all experimental roughnesses and pristine ITO coated glass substrates on days one and seven. By day fourteen, cells cultured on anodized ITO films with roughness of $19 \mathrm{~nm}, 61 \mathrm{~nm}$, and $81 \mathrm{~nm}$ over $10 \mu \mathrm{m}^{2}$ demonstrated reduced FX frequency, and a similar FA distribution profile with lengths ranging from $1 \mu \mathrm{m}$ to $4.5 \mu \mathrm{m}$. However, cells cultured on control ITO substrates were associated with a reduction in FA frequency (Figure 5). It was interesting to note that over a period of fourteen days in culture, cells demonstrated a progressive shift from nascent and unstable focal complexes to 


\section{WILEY-VCH}

more stable focal adhesions. Moreover, analysis of the distribution of focal adhesions in cells cultured on anodized ITO films formed through altered current densities indicates that surface roughness is an important parameter in the regulation of cell adhesion, and SH-SY5Y cells cultured on anodized films of all roughnesses formed significantly more FA than cells cultured on flat control surfaces. ${ }^{[67]}$ Hence, it can be inferred that the influence of film roughness is the predominant factor in the observed increase in focal adhesion frequency. The hypothesis of this study was that anodized ITO films with resulting nanoscale surface roughness can enhance FA formation in neural cells. The result of this study supports this hypothesis, and the number of FAs in SH-SY5Y neuroblastoma cells was increased on films of all roughnesses. Similarly, studies with nanoscale pillars by Mokarian-Tabari et al ${ }^{[68]}$ also reported that the inclusion of nanoscale features promoted increased neural cell adhesion on silicon substrates through the generation of elongated FAs. Conversely, this study utilized an ordered and well-defined monophasic nanotopography, with feature dimensions in the region of $20 \mathrm{~nm}$. It can be inferred that the colloidal features resulting through anodic oxidization of ITO and manifest as surface roughness may be suboptimal as a modulator of cell adhesion and that coating/electrode modification through the nanoimprinting of well-defined nanoscale feature such as those reported by Yang et al ${ }^{[69]}$ may offer a more effective methodology for regulation of cellular adhesion.

\subsection{Functional Characterization}

The ability of anodized ITO to interface neuronal circuit formation was subsequently explored via patch-clam analysis. In particular, the functional response was explored using explanted primary neurons on ITO anodized at the lowest current density $\left(0.4 \mathrm{~mA} \mathrm{~cm}{ }^{-2}\right)$ via two functional indicators: network formation and synaptic activity. ${ }^{[70]}$ Rat hippocampal cells, from which primary neuronal cultures were grown and maintained for eight to ten days on ITO anodized films formed at a current density of $0.4 \mathrm{~mA} \mathrm{~cm}^{-2}$ was compared to control cultures grown on poly-L-ornithine coated glass coverslips. Hippocampal neuron maturation and 


\section{WILEY-VCH}

viability were assessed using single-cell recordings (see Experimental Section). Visually identified neurons from the two culture groups were patch clamped under voltage clamp modality to measure the cell passive membrane properties which are known indicators of neuronal health. ${ }^{[71-73]}$ These parameters (input resistance and membrane capacitance) did not differ ( $\mathrm{P}=0.221$ and $\mathrm{P}=0.369$ for input resistance and cell capacitance, respectively) when measured in the two culture conditions (see bar plots in Figure 6C). We investigated synapse formation and activity after in vitro growth of neurons by measuring in both culture groups the occurrence of spontaneous postsynaptic currents (PSCs). The appearance of PSCs provided clear evidence of functional synapse formation which is a widely accepted index of network efficacy. ${ }^{[70]}$

Figure 6A, shows representative current tracings of the recorded electrical activity. PSC amplitude and frequency were measured from neurons grown in control and $0.4 \mathrm{~mA} \mathrm{~cm}-2$ anodized ITO films. As summarized in the bar plots of Figure 6B, these values were not statistically different $(\mathrm{P}=0.988$ and $\mathrm{P}=0.247$, amplitude and frequency, respectively) in the two groups of cultures and were consistent with those measured in other studies testing the permissive nature of manufactured interfaces. ${ }^{[74]}$ The impact on cells of the modified substrate is, therefore, negligible. In Figure 6D the cellular composition of control and anodized ITO film hippocampal cultures is shown, assessed by immunofluorescence markers ${ }^{[75]}$ for astrocytes (GFAP) and neurons ( $\beta$-tubulin III). It was observed both $\beta$-tubulin III and GFAP immunoreactive cells in all growing conditions (Figure 6D left and right panels) and both cell groups were represented in a comparable proportion in all experimental groups (quantified by measuring the cell density, bar plot in Figure $6 \mathrm{E} ; \mathrm{P}=0.415,30$ visual fields per condition, three different culture series). Thus cell survival and the global network size were not affected by ITO anodized film formed at current density of $0.4 \mathrm{~mA} \mathrm{~cm}{ }^{-2}$. 


\section{WILEY-VCH}

\section{Conclusion}

Here we employed a range of current densities for the anodization of ITO in an aqueous cytocompatible electrolyte and investigated the effects of current densities on film electrochemical, physical and cytocompatibility properties.

This work provides a useful bench-mark for anodization film deposition conditions for our subsequent studies with neural microelectrodes, micro-patterning and biochemical functionalization. The roughness of the dielectric has been proven to be an important factor for semiconductor growth and charge carrier mobility. Interestingly, the ability to anodize ITO films with differential properties for charge transfer and resistivity may provide a facile approach to the deposition of electrode coatings with differential regions of charge conductance capacities. It can be hypothesized that anodization with varying current densities may be employed to deposit insulator and charge carrier regions on a single electrode system, providing cytocompatible coatings with defined regions capable of applying localized stimulation.

\section{Experimental Section}

\subsection{Anodic Oxidation of ITO}

The anodic oxidation of ITO was conducted under ambient conditions in a solution of $10 \mu \mathrm{M}$ PSS (Sigma Aldrich, Ireland, 70,000 $\mathrm{g} \mathrm{mol}^{-1} \mathrm{MW}$ ) prepared in a $0.01 \mathrm{M}$ phosphate-buffered saline solution (PBS) with a platinum foil as a counter electrode (cathode). The electrolyte solution was placed in an in-house fabricated electrochemical cell, connected to a Princeton Applied Research Potentiostat/Galvanostat model 2273 controlled with Power Suite software. Pristine ITO coated glass slides were purchased from diamondcoatings, UK. These were provided as thin-films sputter-coated onto glass substrates with a nominal thickness of $750 \mathrm{~nm}$ and sheet resistivity of $8-10 \mathrm{Ohms} \mathrm{sq}^{-1}$. Pristine ITO coated glass slides were individually cleaned in acetone, dried with a stream of nitrogen and moved to a desiccating chamber to remove moisture for 24 hours prior to use. Galvanostatic anodization was performed applying 


\section{WILEY-VCH}

constant current densities of $0.4 \mathrm{~mA} \mathrm{~cm}^{-2}, 4 \mathrm{~mA} \mathrm{~cm}^{-2}$ and $43 \mathrm{~mA} \mathrm{~cm}^{-2}$ over a constant time of 450 seconds to pristine ITO coated glass. A schematic representation of the anodization process is presented in Figure $\mathbf{S 1 .}$

\subsection{Physical Characterization}

\subsubsection{Surface Morphology}

Scanning electron microscopy (SEM) was carried out using a Hitachi S-4700 Cold Field Emission Gun Scanning Electron Microscope (CFE-SEM). The SEM images were taken using an accelerating voltage of $15 \mathrm{kV}$ and spot current of $10 \mu \mathrm{A}$. Gold sputtering was carried out before testing the samples using an EMSCOPE SC500 to deposit $10 \mathrm{~nm}$ of gold.

Atomic Force Microscopy (AFM) was performed to analyze the roughness of the samples. All measurements were taken on a Vico Dimension 3100 AFM using TESPA Tips (NanoWorld) ( $\mathrm{Si}<8 \mathrm{~nm}$ tip radius, $42 \mathrm{~N} / \mathrm{m}$ spring constant, $320 \mathrm{kHz}$ nominal resonance frequency), in tapping mode over an area of $10 \mu \mathrm{m}^{2}$ and $10 \mu \mathrm{m}^{2}$ respectively with a $0.5-1 \mathrm{~Hz}$ scan rate.

\subsubsection{Thickness Measurements}

The thickness of the anodized films was measured using a Zygo Newview 100 surface profilometer controlled by MicroPlus software. A pattern of bright and dark lines - fringes was created as incoming light was split from the limited region between the anodized film and the pristine ITO glass. This pattern difference was translated to calculate the height information, resulting in the thickness of the film. The size of the testing area was $1.6 \mathrm{~cm}^{2}$.

\subsubsection{UV-visible Spectroscopy}

The optical transmittance of the ITO coated glass and the anodized films was assessed by using a Thermo Scientific Varios- Kan Flash microplate reader at the visible-light wavelengths (400-800 nm).

\subsection{Chemical Characterization}

X-ray photoelectron spectroscopy (XPS) spectra were acquired on an Oxford Applied Research Escabase XPS system equipped with a CLASS VM $100 \mathrm{~mm}$ mean radius 


\section{WILEY-VCH}

hemispherical electron energy analyser with a triple-channel detector arrangement in an analysis chamber with a base pressure of $5.0 \times 10-10$ mbar. Survey scans were acquired between $0-1100 \mathrm{eV}$ with a step size of $0.7 \mathrm{eV}$, dwell time of $0.5 \mathrm{~s}$ and pass energy of $100 \mathrm{eV}$. Core level scans were acquired at the applicable binding energy range with a step size of 0.1 $\mathrm{eV}$, dwell time of $0.5 \mathrm{~s}$ and pass energy of $50 \mathrm{eV}$ averaged over 50 scans. A nonmonochromated Mg-ka x-ray source at $200 \mathrm{~W}$ power was used for all scans. All spectra were acquired at a take-off angle of $90^{\circ}$ with respect to the analyzer axis and were charge corrected with respect to the $\mathrm{C} 1$ s photoelectric line by rigidly shifting the binding energy scale to 285 eV. Data were processed using CasaXPS software where a Shirley background correction was employed and peaks were fitted to Voigt profiles. To ensure accurate quantification, atomic sensitivity factors were taken from the instrument spectrum acquisition software and manually input into the data processing software.

FTIR spectra were obtained using a Perkin Elmer Spectrum One spectrometer with a universal ATR accessory. Spectra were collected between $600-3600 \mathrm{~cm}^{-1}$, with a resolution of $4 \mathrm{~cm}^{-1}$ and integrating 32 scans. A force of $50 \mathrm{kN}$ was applied to collect the spectrum of PSS, while no force was applied during the collection of spectra from the films. A background scan of the ITO-coated glass was used for the processing of the films to remove the effect of the silicate stretches.

\subsection{Electrochemical Characterization}

\subsubsection{Electrochemical Measurements}

Cyclic voltammetry was performed using a $\mathrm{CH}$ Instruments 620 series potentiostat. Measurements were recorded in a custom-made electrochemical cell (2 mL volume) containing the pristine ITO coated glass as working electrode $\left(1.6 \mathrm{~cm}^{2}\right)$, an $\mathrm{Ag} / \mathrm{AgCl}$ reference electrode ( $3 \mathrm{M} \mathrm{KCl}$ ) (Bioanalytical Systems) and a platinum foil counter electrode (Goodfellow) in $50 \mathrm{mM}$ phosphate buffer solution ( $\mathrm{pH}$ 7.8) or saline solution. ${ }^{[76]}$ Prior to 


\section{WILEY-VCH}

measurements, solutions were purged with $\mathrm{N}_{2}$ to avoid $\mathrm{O}_{2}$ reduction at low potentials $(<-0.4$ V vs. $\mathrm{Ag} / \mathrm{Ag} / \mathrm{Cl})$.

Electrical impedance spectroscopy (EIS) was performed using a Princeton Applied Research Potentiostat/Galvanostat model 2273 running with Power Suite software with a four electrode set-up as described in ${ }^{[7]}$. The signal was to the anodized films with a surface area of $1.6 \mathrm{~cm}^{2}$, in a-physiological saline electrolyte buffered with carbonate and phosphate as described in ${ }^{[76]}$, along with a platinum foil counter-electrode (CE) and controlled by a saturated $\mathrm{Ag} / \mathrm{AgCl}$ reference electrode. An AC sine wave of $40 \mathrm{mV}$ amplitude was applied with $0 \mathrm{~V}$ DC offset. The impedance magnitude and phase angle were calculated at 1, 10, 100, 1000, $10000 \mathrm{~Hz}$, as it is reported that most of the neural cell communication occurs between $300 \mathrm{~Hz}$ and $1 \mathrm{kHz}{ }^{[77]}$. Values were presented on a Bode plot and compared to pristine ITO glass slide and to bare gold coated glass.

\subsection{Biological Characterization}

\subsubsection{Cell culture}

The human neuroblastoma cell line SH-SY5Y was cultured in Dulbeccos Modified Eagles Medium nutrient mixture F12 (DMEM/F12) medium and supplemented with $10 \%$ fetal bovine serum (FBS), 1\% penicillin/streptomycin and all-trans retinoic acid at a final concentration of $10 \mu \mathrm{M}$ for differentiation into a neuronal phenotype. To control the surface area of culture, the pristine ITO coated glass and the anodized films were placed in customized silicone Ace O-rings with wall dimension of $1.78 \mathrm{~mm}$ and I.D of $10.8 \mathrm{~mm}$ and were sealed around the borders of the surface area with silicone elastomer (Sylgard 184). The materials were placed in six well culture plates and sterilized by $100 \%$ ethanol for two hours, and subsequently washed repeatedly with Hank's balanced salt solution (HBSS) and incubated overnight at $37^{\circ} \mathrm{C}, 5 \% \mathrm{CO}_{2}$ for neural cell culture. A quantity of 50,000 or 2,000 cells $\mathrm{cm}^{-2}$ was plated on each film, and then $200 \mu$ of the culture medium was added to each 


\section{WILEY-VCH}

well, and changed with fresh media every day for a period of one, seven or fourteen days. Control Thermanox ${ }^{\circledR}$ Plastic Coverslips with $13 \mathrm{~mm}$ diameter (NUNC ${ }^{\mathrm{TM}}$ brand products) were also bonded with silicone Ace O-rings as above.

Primary hippocampal cultures were prepared from two-three days postnatal $\left(\mathrm{P}_{2}-\mathrm{P}_{3}\right)$ rats as previously reported by Cellot et al. ${ }^{[70]}$ Briefly, hippocampi were dissected and enzymatically digested. Cells were plated on poly-L-ornithine coated glass coverslips (control) or on anodized ITO substrates formed at $0.4 \mathrm{~mA} \mathrm{~cm}{ }^{-2}$ current density. Coverslips were placed in petri dishes and cultured in serum-containing medium in a $5 \% \mathrm{CO}_{2}$ - humified incubator for eight to ten days. Cell morphology was analyzed by immunofluorescence experiments and epifluorescence microscopy to gain insights into cell health and shape. Briefly, cell densities were quantified at 20x (0.5 NA) magnification using a DM6000 Leica microscope (Leica Microsystems GmbH, Wetzlar, Germany), with random sampling of visual fields (713 x 532 $\mu \mathrm{m})$.

\section{Ethical Statement}

All experiments were performed in accordance with the EU guidelines (2010/63/UE) and Italian law (decree 26/14) and were approved by the local authority veterinary service and by our institution (SISSA-ISAS) ethical committee. Every effort was made to minimize animal suffering and to reduce the number of animals used. Animal use was approved by the Italian Ministry of Health, in accordance with the EU Recommendation 2007/526/CE.

\subsubsection{Metabolic analysis}

The alamarBlue ${ }^{\circledR}$ Assay (Life Technologies, UK) was used to assess cell metabolism and was carried out at day one, day seven and day fourteen. For this purpose, $10 \%$ of the alamarBlue® solution was added to the culture media, in accordance with the provided protocols. Sample absorbance was measured in a 96 well plate at 544 excitation and 590 emission wave lengths using a Thermo Scientific Varios- Kan Flash microplate reader. 


\section{WILEY-VCH}

\subsubsection{Immunofluorescent labeling}

Indirect double-immunoflourescent labelling was performed to visualize focal adhesion sites. SH-SY5Y cells on experimental and control substrates were fixed with $4 \%$ paraformaldehyde and $1 \%$ of sucrose for fifteen minutes at room temperature at each time point. Once fixed, the samples were washed with PBS and permeabilized with buffered $0.5 \%$ Triton X-100 within a buffered isotonic solution (10.3 $\mathrm{g}$ sucrose, $0.292 \mathrm{~g} \mathrm{NaCl}, 0.06 \mathrm{~g} \mathrm{MgCl}$, $0.476 \mathrm{~g}$ HEPES buffer, $0.5 \mathrm{ml}$ Tri- ton $\mathrm{X} 100$, in $100 \mathrm{ml}$ water, $\mathrm{pH}$ 7.2) at $4^{\circ} \mathrm{C}$ for five minutes. Non-specific binding sites were blocked with $1 \%$ bovine serum albumin (BSA) in PBS at $37^{\circ} \mathrm{C}$ for five minutes and subsequently incubated for two hours with a 1:100 concentration anti-vinculin (Rb mAb to Paxillin (Y113) (Life Technologies, 1:100). Samples were washed three times with $0.05 \%$ Tween 20 , PBS and then incubated for one hour in the secondary antibody Alexa Fluor® 488 goat anti-Rabbit IgG (H+L) (Life Technologies, 1:100) combined with rhodamine-conjugated phalloidin (Life Technologies, 1:100) to stain F-actin. Non-specific charges (e.g. remaining aldehyde) were neutralized with $0.5 \%$ Tween $20 / \mathrm{PBS}(5 \mathrm{~min} \times 3)$ to minimize background labeling. Samples were mounted on microscope cover slides and counterstained with slowfade ${ }^{\mathrm{R}}$ gold antifade reagent with Dapi for nuclear staining.

For immunofluorescence experiments on primary neurons, cultures were fixed with $4 \%$ formaldehyde (prepared from fresh paraformaldehyde) in PBS for 60 minutes at RT and then washed in PBS. The samples were permeabilized with $0.3 \%$ Triton-X-100 and subsequently incubated with primary antibodies for $30 \mathrm{~min}$ at room temperature, washed with PBS and incubated with secondary antibodies for $45 \mathrm{~min}$. Cultures were then mounted in Vectashield (Vector Laboratories) on $1 \mathrm{~mm}$ thick microscope slides. To visualize neurons rabbit anti $\beta$ tubulin III, 1:250 (SIGMA) primary antibody was used and Alexa 594 goat anti rabbit secondary antibody, 1:500 (Invitrogen); to visualize astrocytes mouse anti Glial-Fibrillary acidic protein (GFAP) 1:250 (SIGMA) primary antibody was used and Alexa 488 goat anti 


\section{WILEY-VCH}

mouse secondary antibody 1:500 (Invitrogen), and Hoeschst (Invitrogen) was used to visualize cell nuclei.

\subsubsection{Microscopy and image analysis}

After immunostaining, samples were viewed with an Olympus IX 81 fluorescence microscope with filters for FITC (excitation $490 \mathrm{~nm}$; emission $520 \mathrm{~nm}$ ), TexasRed (excitation $596 \mathrm{~nm}$; emission $615 \mathrm{~nm}$ ) and DAPI (excitation $358 \mathrm{~nm}$; emission $461 \mathrm{~nm}$ ). At least twenty randomly selected images at 60x magnification were taken from each test group and the control group. The total number of focal adhesion points per cell and their length were quantified by direct scoring with a 4 pixel-wide line on the FITC channel as previously described in [60] using ImageJ software (National Institutes of Health, USA) (Figure S6).

Cell densities were quantified at 20x (0.5 NA) magnification using a DM6000 Leica microscope (Leica Microsystems GmbH, Wetzlar, Germany), with random sampling of seven to ten fields ( $713 \times 532 \mu \mathrm{m}$; control and anodized film, $\mathrm{n}=3$ culture series $)$.

\subsection{Electrophysiological Recordings}

Single whole-cell recordings were obtained at room temperature (RT) with pipettes (5-7 M 2 ) containing (in $\mathrm{mM}$ ): $120 \mathrm{~K}$ gluconate, $20 \mathrm{KCl}, 10 \mathrm{HEPES}, 10 \mathrm{EGTA}, 2 \mathrm{MgCl}_{2}, 2 \mathrm{Na}_{2} \mathrm{ATP}$, $\mathrm{pH}$ 7.3; osmolarity was adjusted to $300 \mathrm{mOsm}$. The extracellular solution contained (in $\mathrm{mM}$ ): $150 \mathrm{NaCl}, 4 \mathrm{KCl}, 1 \mathrm{MgCl}_{2}, 2 \mathrm{CaCl}_{2}, 1 \mathrm{MgCl}_{2}, 10$ HEPES, 10 glucose (all Sigma), pH 7.4. Coverslips with cultures were positioned in a Perspex chamber mounted on an inverted microscope (Eclipse TE-200, Nikon, Japan). Data were collected by Multiclamp 700B patch amplifier (Axon CNS, Molecular Devices) and digitized at $10 \mathrm{kHz}$ with the pClamp 10.2 acquisition software (Molecular Devices LLC, US). The spontaneous synaptic activity was recorded clamping the membrane voltage at $-56 \mathrm{mV}$ holding potential (not corrected for liquid junction potential, that was $14 \mathrm{mV}$ ). All recorded events were analyzed off-line with the AxoGraph 1.4.4 (Axon Instrument) event detection software (Axon CNS, Molecular Devices). 


\section{WILEY-VCH}

\subsection{Statistical analysis}

All data presented here was confirmed using at least three replicates for each of the test groups and control group. The results are expressed as the mean of the values \pm standard error of the mean. One-way ANOVA followed by a Bonferroni test were performed to determine the statistical significance $(\mathrm{p}<0.05)$, unless otherwise stated.

For the hippocampal cultures electrophysiology and immunofluorescence analysis, all values from samples subjected to the same experimental protocols were pooled and expressed as mean \pm S.D. with $n=$ number of cells, unless otherwise specified. Where not otherwise indicated, statistically significant differences between datasets were assessed by Student's t test (after validation of variances homogeneity by Levene's test) for parametric data at a minimum significance level of $\mathrm{P}<0.05$.

\section{Supporting Information}

Supporting Information is available from the Wiley Online Library or from the author.

\section{Acknowledgements}

This publication has emanated from research supported in part by a research grant from Science Foundation Ireland (SFI) and is co-funded under the European Regional Development Fund under Grant Number 13/RC/2073. M.J. Biggs is also an SFI, Starting Investigator SIRG COFUND fellow, grant no. 11/SIRG/B2135. The authors would like to acknowledge Advanced Materials and BioEngineering Research (AMBER) and Science Foundation Ireland (SFI) for funding through SFI-AMBER (grant no. SFI 12/RC/2278 AMBER). The authors would like to acknowledge the joint funding received from Irish Research Council through IRC New Foundation Scheme/Nano Surface project, the NUI Galway microscopy suite and Mr David Connolly for microscopy support.

Received: ((will be filled in by the editorial staff))

Revised: ((will be filled in by the editorial staff)) Published online: ((will be filled in by the editorial staff)) 


\section{WILEY-VCH}

[1] C. Vallejo-Giraldo, A. Kelly, M. J. Biggs, Drug Discov. Today, 2014, 19(1), 88

[2] G. M. Durand DM, Krames E, J Neural Eng. 2014

[3] T. D. Kozai, N. B. Langhals, P. R. Patel, X. Deng, H. Zhang, K. L. Smith, J. Lahann, N. A. Kotov, D. R. Kipke, Nat Mater. 2012, 11(12), 1065

[4] L. S. R. a. T. L. Rose, Neural Prostheses: Fundamental Studies, Prentice Hall, Englewood Cliffs, NJ 1990

[5] S. F. Cogan, Rev. Biomed. Eng. 2008, 10, 275.

[6] H. Zhou, X. Cheng, L. Rao, T. Li, Y. Y. Duan, Acta Biomater. 2013, 9(5), 6439

[7] C. Vallejo-Giraldo, E. Pugliese, A. Larrañaga, M.A. Fernandez- Yague, J.J. Britton, , A.Trotier, G. Tadayyon, A. Kelly, I. Rago, J.R. Sarasua, E. Dowd, L.R. Quinlan, A. Pandit, M.J.P Biggs, Nanomedicine (Lond). 2016, In press.

[8] O. J. Gregory, Q. Luo, E. E. Crisman, Thin Solid Films. 2002, 406(1-2), 286

[9] B. W. Faughnan, R. S. Crandall, Top Appl Phys. 1980, 40, 181

[10] L. J. Meng, C. H. Li, G. Z. Zhong, J. Lumin. 1987, 39(1), 11

[11] J. R. Bellingham, A. P. Mackenzie, W. A. Phillips, Appl. Phys. Lett. 1991, 58(22), 2506

[12] B. J. Luff, J. S. Wilkinson, G. Perrone, Appl. Opt. 1997, 36(27), 7066

[13] A. C. Weitz, M. R. Behrend, A. K. Ahuja, P. Christopher, J. Wei, V. Wuyyuru, U. Patel, R. J. Greenberg, M. S. Humayun, R. H. Chow, J. D. Weiland, J Neural Eng. 2014, 11(1), 016007

[14] A. C. Weitz, M. R. Behrend, N. S. Lee, R. L. Klein, V. A. Chiodo, W. W. Hauswirth, M. S. Humayun, J. D. Weiland, R. H. Chow, J Neurophysiol. 2013, $109(7), 1979$

[15] R. Tanamoto, Y. Shindo, N. Miki, Y. Matsumoto, K. Hotta, K. Oka, J Neurosci Methods. 2015, 253, 272

[16] Q. Qiu, M. Sayer, M. Kawaja, X. Shen, J. E. Davies, J Biomed Mater Res. 1998, 42(1), 117

[17] S. Petronis, M. Stangegaard, C. B. Christensen, M. Dufva, Biotechniques. 2006, 40(3), 368

[18] Y. Nashimoto, Y. Takahashi, T. Yamakawa, Y. S. Torisawa, T. Yasukawa, T. ItoSasaki, M. Yokoo, H. Abe, H. Shiku, H. Kambara, T. Matsue, Anal Chem. 2007, 79(17), 6823

[19] M. L. Guo, J. H. Chen, X. B. Yun, K. Chen, L. H. Nie, S. Z. Yao, Bba-Gen Subjects. 2006, 1760(3), 432

[20] J. Selvakumaran, M. P. Hughes, J. L. Keddie, D. J. Ewins, presented at 2nd Annual International IEEE-EMBS Special Topic Conference on Microtechnologies in Medicine \& Biology, Madison, Wisconsin, USA, May, 2002

[21] H. Pluk, D. Stokes, B. Lich, B. Wieringa, J. Fransen, J Microsc-Oxford. 2009, 233(3), 353

[22] C. M. Bowers, A. A. Shestopalov, R. L. Clark, E. J. Toone, ACS Appl Mater Interfaces. 2012, 4(8), 3932

[23] C. J. Huang, Y. K. Su, S. L. Wu, Mater. Chem. Phys. 2004, 84(1), 146

[24] P. K. H. Ho, M. Granstrom, R. H. Friend, N. C. Greenham, Adv Mater. 1998, 10(10), 769

[25] J. L. Robinson, P. F. King, J. Electrochem. Soc. 1961, 108(1), 36

[26] N. Cabrera, N. F. Mott, Rep Prog Phys. 1948, 12, 163

[27] S. W. Cho, J. G. Jeong, S. H. Park, M. H. Cho, K. Jeong, C. N. Whang, Y. Yi, ppl. Phys. Lett. 2008, 92(21)

[28] G. R. T. Schueller, S. R. Taylor, E. E. Hajcsar, J. Electrochem. Soc. 1992, 139(10), 2799

[29] C. Blawert, W. Dietzel, E. Ghali, G. L. Song, Adv Eng Mater. 2006, 8(6), 511

[30] M. V. Diamanti, B. Del Curto, M. Pedeferri, J Appl Biomater Biomech. 2011, 9(1), 55 


\section{WILEY-VCH}

[31] L. E. McNamara, T. Sjostrom, K. E. V. Burgess, J. J. W. Kim, E. Liu, S. Gordonov, P. V. Moghe, R. M. D. Meek, R. O. C. Oreffo, B. Su, M. J. Dalby, Biomaterials. 2011, 32(30), 7403

[32] H. Tsuchiya, J. M. Macak, A. Ghicov, L. Taveira, P. Schmuki, Corros. Sci.. 2005, 47(12), 3324

[33] A. Ghicov, H. Tsuchiya, J. M. Macak, P. Schmuki, Electrochem. Commun. 2005, 7(5), 505

[34] S. Mahshid, A. Dolati, M. Goodarzi, M. Askari, A. Ghahramaninezhad, Nanotechnology (General) - 217th Ecs Meeting, Vancourver, Canada, 2010

[35] T. Tian, X. F. Xiao, R. F. Liu, H. D. She, X. F. Hu, J. Mater. Sci. 2007, 42(14), 5539

[36] S. Bauer, S. Kleber, P. Schmuki, Electrochem. Commun. 2006, 8(8), 1321

[37] E. E. L. Swan, K. C. Popat, C. A. Grimes, T. A. Desai, J Biomed Mater Res A. 2005, $72 A(3), 288$

[38] T. R. B. Foong, A. Sellinger, X. Hu, Acs Nano. 2008, 2(11), 2250

[39] G. Folcher, H. Cachet, M. Froment, J. Bruneaux, Thin Solid Films. 1997, 301(1-2), 242

[40] A. Kraft, H. Hennig, A. Herbst, K. H. Heckner, J. Electroanal. Chem. 1994, 365(1-2), 191

[41] Y. Shao, X. Xiao, L. Y. Wang, Y. Liu, S. D. Zhang, Adv Funct Mater. 2014, 24(26), 4170

[42] E. Matveeva, J. Electrochem. Soc. 2005, 152(9), H138

[43] M. Senthilkumar, J. Mathiyarasu, J. Joseph, K. L. N. Phani, V. Yegnaraman, Mater. Chem. Phys. 2008, 108(2-3), 403

[44] L. Liu, S. Yellinek, I. Valdinger, A. Donval, D. Mandler, Electrochim Acta. 2015, 176, 1374

[45] J. Stotter, Y. Show, S. H. Wang, G. Swain, Chem Mater. 2005, 17(19), 4880

[46] R. Castro-Rodriguez, A. I. Oliva, V. Sosa, F. Caballero-Briones, J. L. Pena, Appl. Surf. Sci. 2000, 161(3-4), 340

[47] G. Kavei, A. M. Gheidari, J Mater Process Tech. 2008, 208(1-3), 514

[48] C. Yao, T. J. Webster, J Nanosci Nanotechnol. 2006, 6(9-10), 2682

[49] J. F. Vanhumbeeck, J. Proost, Corros. Rev. 2009, 27(3), 117

[50] A. Paul, J. Wingbermuhle, Appl. Surf. Sci. 2006, 252(23), 8151

[51] A. Facchetti, M. H. Yoon, T. J. Marks, Adv Mater. 2005, 17(14), 1705

[52] A. Solieman, M. A. Aegerter, Thin Solid Films. 2006, 502(1-2), 205

[53] M. Montecchi, R. M. Montereali, E. Nichelatti, Thin Solid Films. 2001, 396(1-2), 262

[54] X. F. Wei, W. M. Grill, J. Neural Eng. 2009, 6(4)

[55] C. Donley, D. Dunphy, D. Paine, C. Carter, K. Nebesny, P. Lee, D. Alloway, N. R. Armstrong, Langmuir. 2002, 18(2), 450

[56] R. G. Keil, J. Electrochem. Soc. 1986, 133(7), 1375

[57] A. J. F. Bard, L. R, Electrochemical methods: Fundamentals and Applications, New York: Wiley 1980

[58] V. Brunetti, G. Maiorano, L. Rizzello, B. Sorce, S. Sabella, R. Cingolani, P. P. Pompa, Proc Natl Acad Sci U S A. 2010, 107(14), 6264

[59] M. Buttiglione, F. Vitiello, E. Sardella, L. Petrone, M. Nardulli, P. Favia, R. d'Agostino, R. Gristina, Biomaterials. 2007, 28(19), 2932

[60] M. J. Biggs, R. G. Richards, S. McFarlane, C. D. Wilkinson, R. O. Oreffo, M. J. Dalby, $J$ R Soc Interface. 2008, 5(27), 1231

[61] Y. W. Fan, F. Z. Cui, S. P. Hou, Q. Y. Xu, L. N. Chen, I. S. Lee, J Neurosci Methods. 2002, 120(1), 17

[62] S. P. Khan, G. G. Auner, G. M. Newaz, Nanomed. 2005, 1(2), 125 


\section{WILEY-VCH}

[63] M. J. P. Biggs, R. G. Richards, N. Gadegaard, R. J. McMurray, S. Affrossman, C. D. W. Wilkinson, R. O. C. Oreffo, M. J. Dalby, J Biomed Mater Res A. 2009, 91A(1), 195

[64] M. D. Schaller, Oncogene. 2001, 20(44), 6459

[65] M. H. Kim, M. Park, K. Kang, I. S. Choi, Biomater Sci-Uk. 2014, 2(2), 148

[66] M. J. Biggs, R. G. Richards, M. J. Dalby, Nanomed. 2010, 6(5), 619

[67] K. Kang, M. H. Kim, M. Park, I. S. Choi, J Nanosci Nanotechnol. 2014, 14(1), 513

[68] P. Mokarian-Tabari, C. V. -Giraldo, M. Fernandez-Yague, C. Cummins, M. A. Morris, M. J. P. Biggs, J. Mater. Sci. Mater. Med.. 2015

[69] Y. Yang, K. Lee, K. Mielczarek, W. Hu, A. Zakhidov, Nanotechnology. 2011, 22(48), 485301.

[70] G. Cellot, F. M. Toma, Z. K. Varley, J. Laishram, A. Villari, M. Quintana, S.

Cipollone, M. Prato, L. Ballerini, J Neurosci. 2011, 31(36), 12945

[71] J. S. Carp, J Neurophysiol. 1992, 68(4), 1121

[72] Y. Gao, L. Liu, Q. Li, Y. Wang, Neurosci Lett. 2015, 591, 138

[73] U. Djuric, A. Y. Cheung, W. Zhang, R. S. Mok, W. Lai, A. Piekna, J. A. Hendry, P. J. Ross, P. Pasceri, D. S. Kim, M. W. Salter, J. Ellis, Neurobiol Dis. 2015, 76, 37

[74] A. Fabbro, D. Scaini, V. Leon, E. Vazquez, G. Cellot, G. Privitera, L. Lombardi, F. Torrisi, F. Tomarchio, F. Bonaccorso, S. Bosi, A. C. Ferrari, L. Ballerini, M. Prato, ACS Nano. 2016, 10(1), 615

[75] S. Bosi, R. Rauti, J. Laishram, A. Turco, D. Lonardoni, T. Nieus, M. Prato, D. Scaini, L. Ballerini, Sci Rep. 2015, 5, 9562

[76] X. F. Wei, W. M. Grill, J Neural Eng. 2009, 6(4), 046008

[77] R. A. Green, N. H. Lovell, G. G. Wallace, L. A. Poole-Warren, Biomaterials. 2008, 29(24-25), 3393

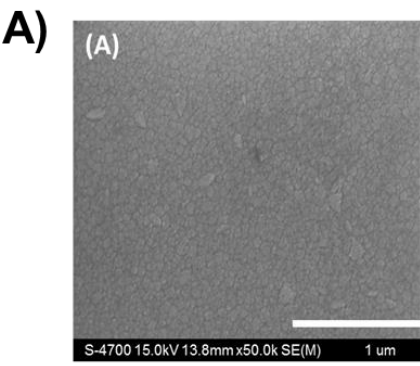

(D) Pristine ITO Glass
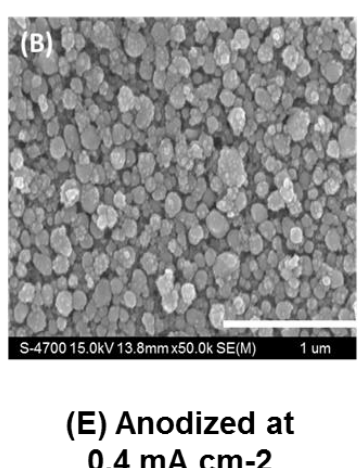
$0.4 \mathrm{~mA} \mathrm{~cm}-2$

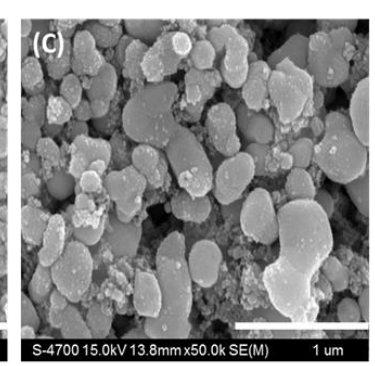

(F) Anodized at $4 \mathrm{~mA} \mathrm{~cm}-2$

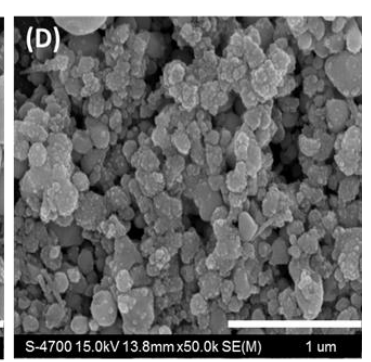

(G) Anodized at $43 \mathrm{~mA} \mathrm{~cm}-2$

B)
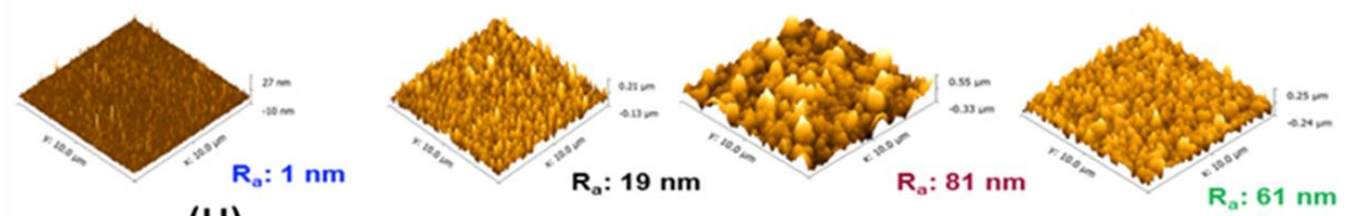

(H)

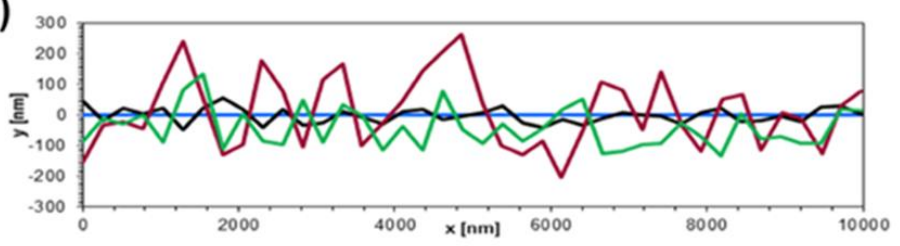

Figure 1. Particle size and distribution are significantly affected by current density. A). Scanning electron micrograms of control pristine ITO coated glass (A) and ITO anodized films electrodeposited with (B). $0.4 \mathrm{~mA} \mathrm{~cm}^{-2}$; (C). $4 \mathrm{~mA} \mathrm{~cm}^{-2}$; and (D). $43 \mathrm{~mA} \mathrm{~cm}^{-2}$ current 


\section{WILEY-VCH}

densities. B). Roughness $\left(\mathrm{R}_{\mathrm{a}}\right)$ measurements of the anodized ITO films with different current densities (D-G) and, representative line profiles $(H)$ from each of the films. Ra indicates the mean surface roughness, calculated on $10 \mu \mathrm{m}^{2}$ regions

A)

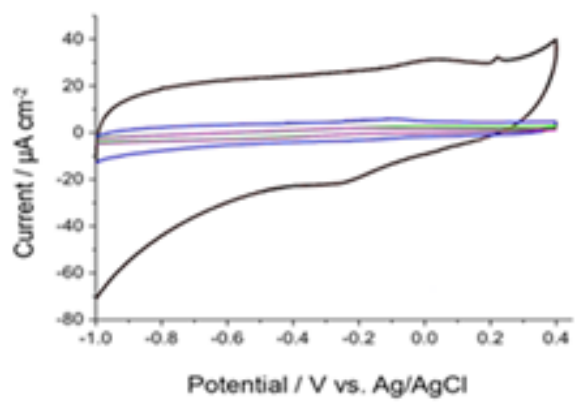

B)

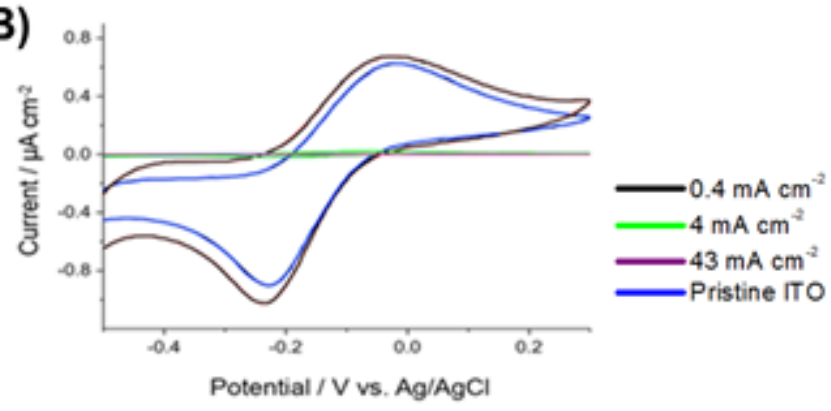

C)

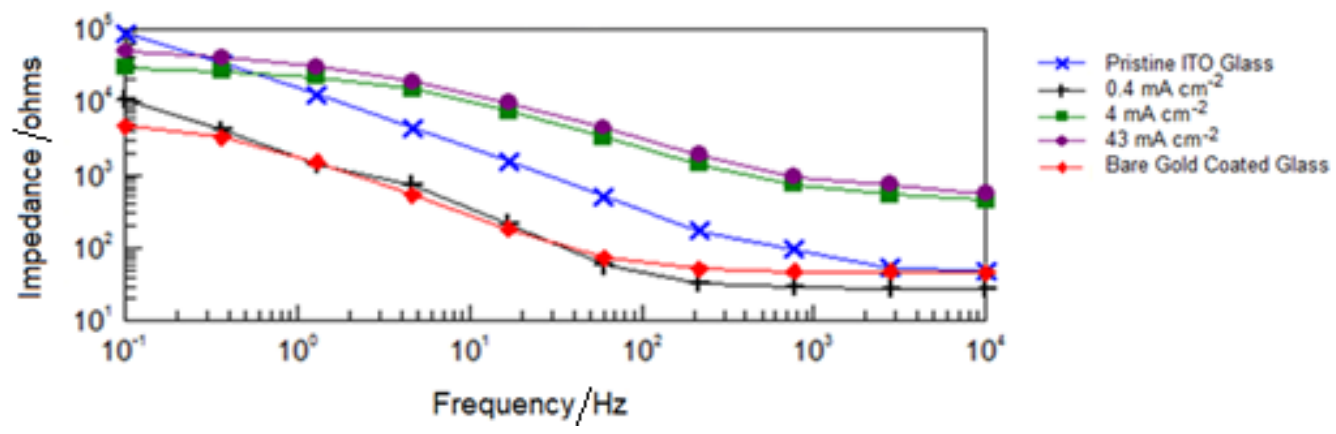

Figure 2. Electrochemical analysis of anodized films. Cyclic voltammograms of ITO (blue) and ITO anodized films formed with current densities; $0.4 \mathrm{~mA} \mathrm{~cm}$ (black), $4 \mathrm{~mA} \mathrm{~cm} \mathrm{~cm}^{-2}$ (green) and $43 \mathrm{~mA} \mathrm{~cm}^{-2}$ (purple). CVs recorded in $50 \mathrm{mM}$ phosphate buffer, scan rate $100 \mathrm{mV}$ $\mathrm{s}^{-1}(\mathrm{~A})$ and in $50 \mathrm{mM}$ phosphate buffer containing $2 \mathrm{mM}\left[\mathrm{Ru}\left(\mathrm{NH}_{3}\right)_{6}\right]^{3+}(\mathrm{B})$, scan rate $100 \mathrm{mV} \mathrm{s}^{-1}$. Bode plot comparing the EIS spectra of pristine ITO glass (blue filled asterisks), bare gold glass (red filled squares), and anodized ITO films formed using $0.4 \mathrm{~mA} \mathrm{~cm}{ }^{-2}$ (black filled crosses), $4 \mathrm{~mA} \mathrm{~cm}^{-2}$ (green filled circles) and $43 . \mathrm{mA} \mathrm{cm}^{-2}$ (purple filled triangles), (C). 


\section{WILEY-VCH}

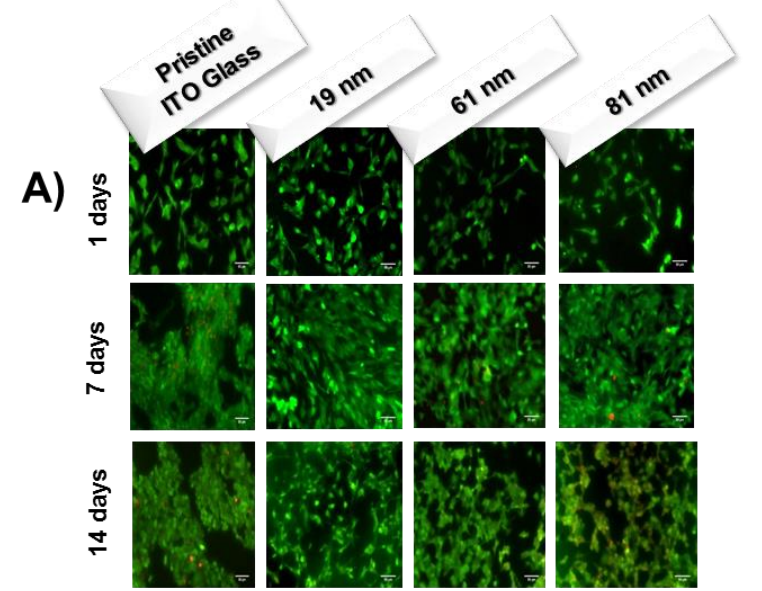

B)

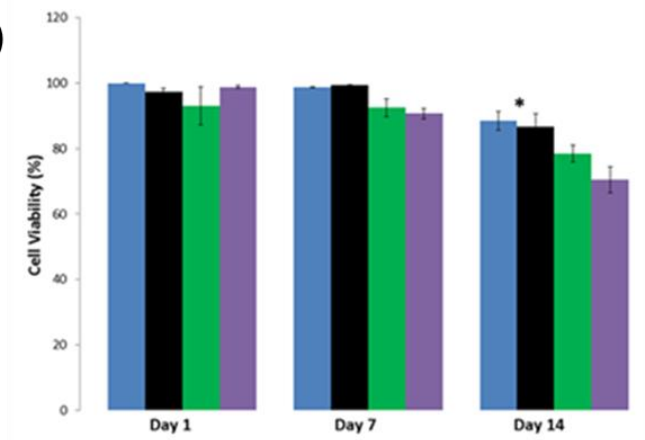

C)
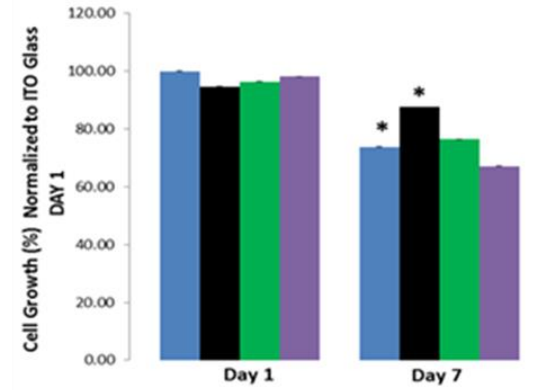

॥ Pristine ITO Glass

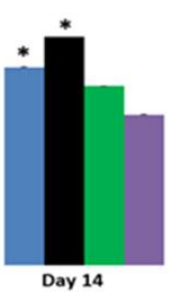

- $19 \mathrm{~nm}$

- $61 \mathrm{~nm}$

| $81 \mathrm{~nm}$

Figure 3. Cytocompatibility analysis of anodized ITO films of different roughness $\left(\mathrm{R}_{\mathrm{a}}\right)$ formed by varying the current density. Fluorescent images of SH-SY5Y cells following 1, 7 and 14 days in culture on anodized films displaying $19 \mathrm{~nm}, 61 \mathrm{~nm}$ and $81 \mathrm{~nm}$ over $10 \mu \mathrm{m}^{2}$ $\left(R_{a}\right)$ roughness relative to pristine ITO control $\left(R_{a} 1 \mathrm{~nm}\right.$ over $\left.10 \mu \mathrm{m}^{2}\right)$. Green, live; red, dead. Bar $=50 \mu \mathrm{m}(\mathrm{A})$. A significant $(\mathrm{p}<0.05)$ decrease in cell viability was observed in anodized films with an average of roughness of $61 \mathrm{~nm}$ and $81 \mathrm{~nm}$ relative to control and $19 \mathrm{~nm}$ film roughness. B. Metabolic activity of SH-SY5Y cells compared with pristine ITO coated glass control as measured by the AlamarBlue assay $(\mathrm{p}<0.05), \mathrm{n}=3$. Metabolic activity was significantly elevated in cells cultured on anodized ITO films with $19 \mathrm{~nm}$ roughness relative to anodized films with 61 and $81 \mathrm{~nm}$ roughness respectively by day 7 and day 14 . Results are $\pm \mathrm{STD}, \star=\mathrm{p}<0.05$.
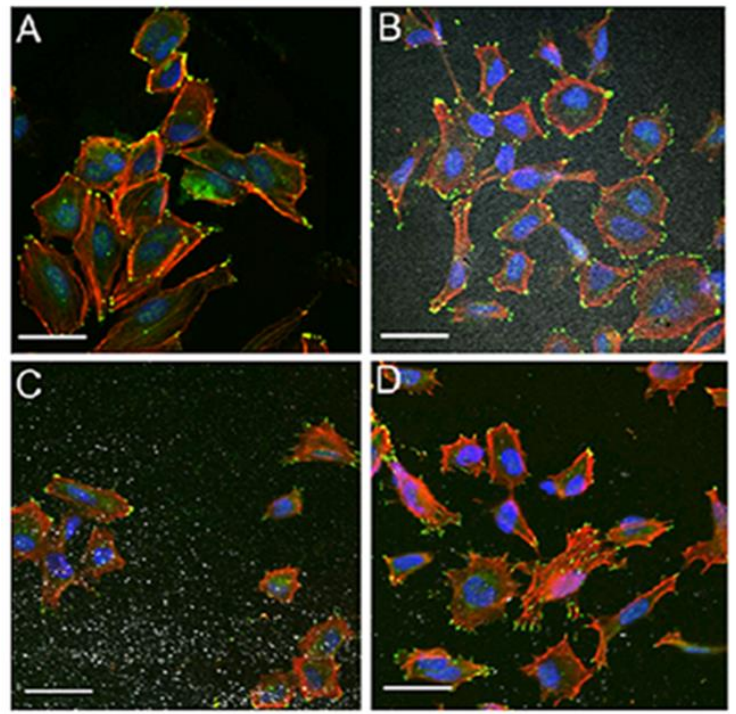

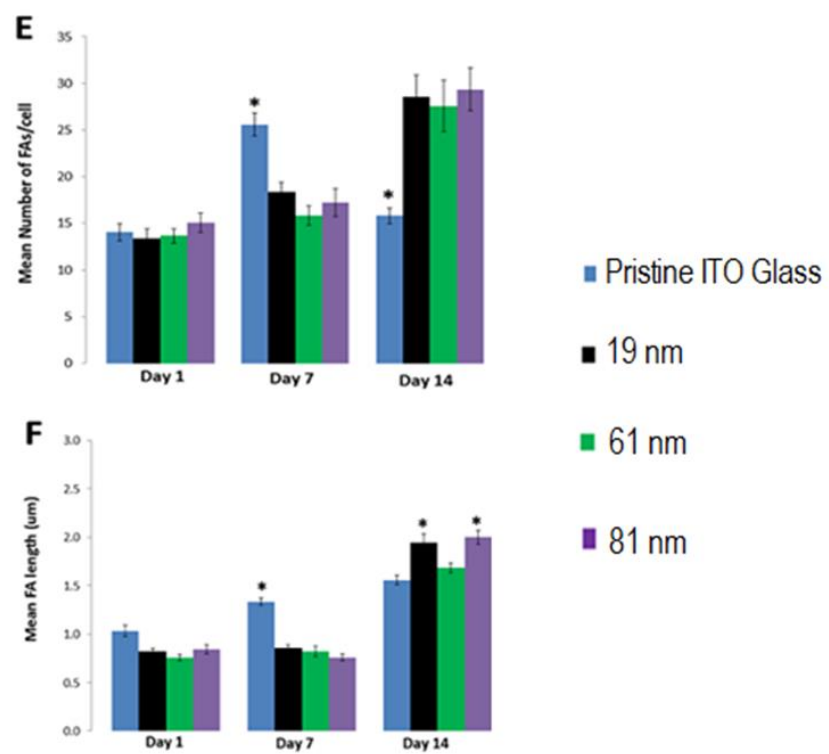




\section{WILEY-VCH}

Figure 4. Focal Adhesion Formation of SH-SY5Y cell grown roughness. Immunofluorescent imaging was employed to quantify FA length and number in cells cultured on pristine ITO coated glass and experimental anodized films of different roughness (A-D) (green: paxillin, red: actin, blue: nucleus, bar: $40 \mu \mathrm{m})$. Cells cultured on control ITO coated glass generated less FA complexes over time, whilst this trend was reversed in cells on experimental anodized ITO films of all roughness (E). SH-SY5Y cells grown on $19 \mathrm{~nm}$, and $81 \mathrm{~nm}$ roughness of anodized films were associated with a significant increase in FA length relative to cells cultured on pristine ITO coated glass $\left(R_{a} 1 \mathrm{~nm}\right)$. There was a significant reduction in cells cultured on $61 \mathrm{~nm}$ roughness compared to the cells grown on $19 \mathrm{~nm}$, and $81 \mathrm{~nm}$ experimental roughnesses (F). For all analysis, results are $\pm S T D, \star=p<0.05$.
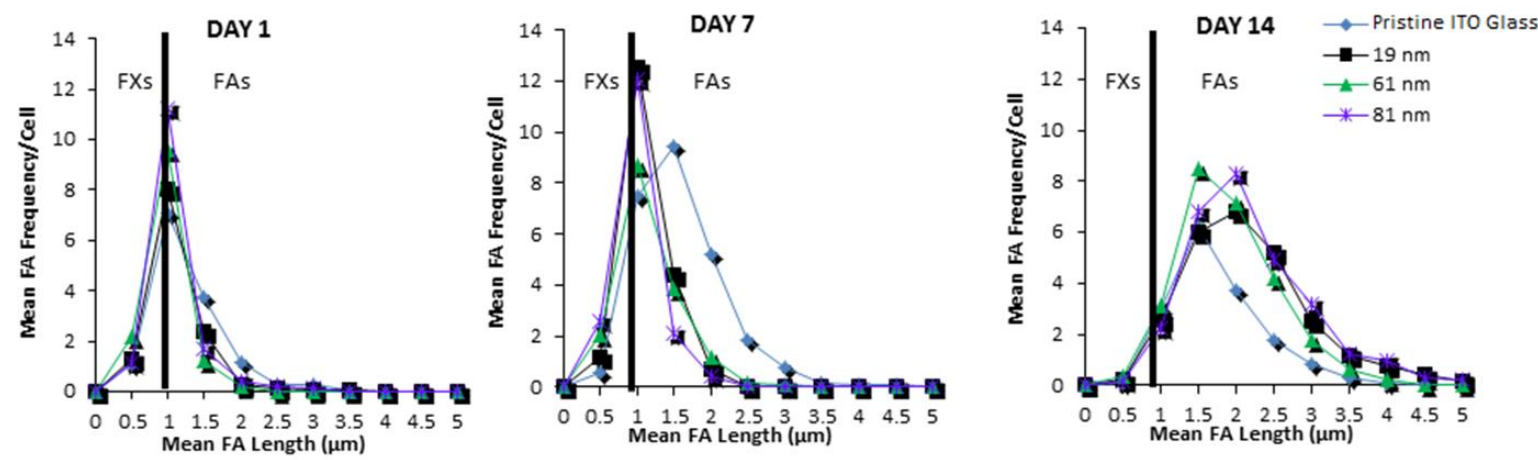

Figure 5. Focal adhesions were sub-grouped into focal adhesions proper (FAs) and nascent focal complexes (FX). FXs were the predominant adhesion complex subtype observed on all anodized ITO films and the pristine ITO coated glass up to day 7. However, FXs were displaced by the FA subtype by day 14 in cells cultured on all experimental and control materials. A significant increase in the mean number of focal adhesions per cell on all of the experimental anodized ITO films compared to control pristine ITO group was observed on day $14, n=3$. 


\section{WILEY-VCH}

A)
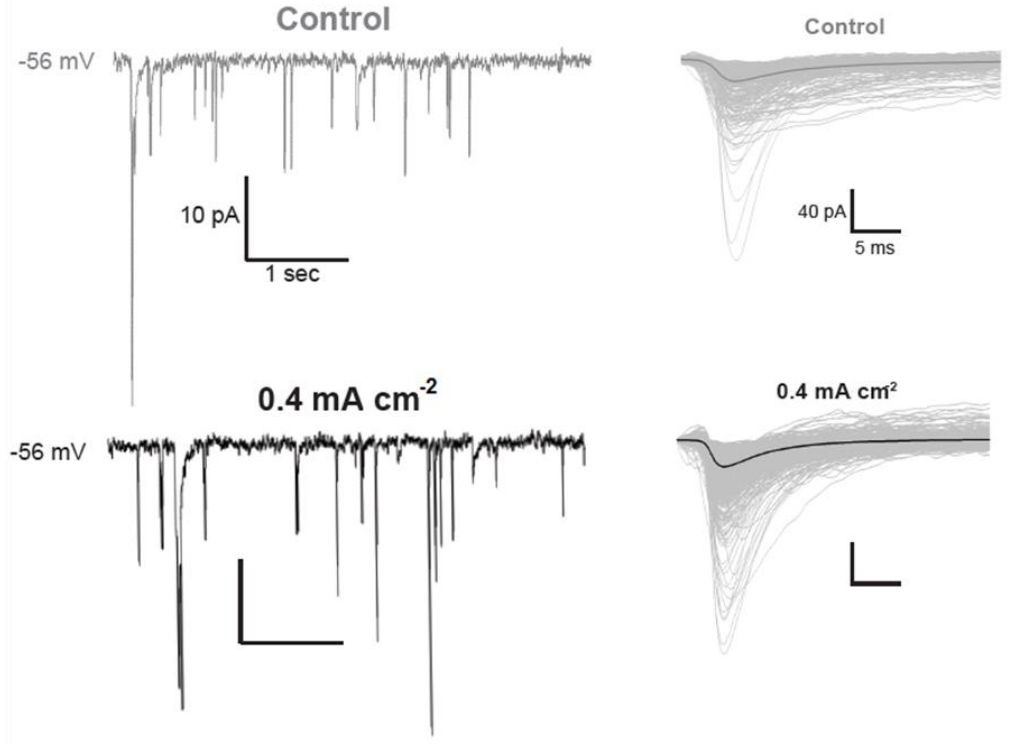

B)
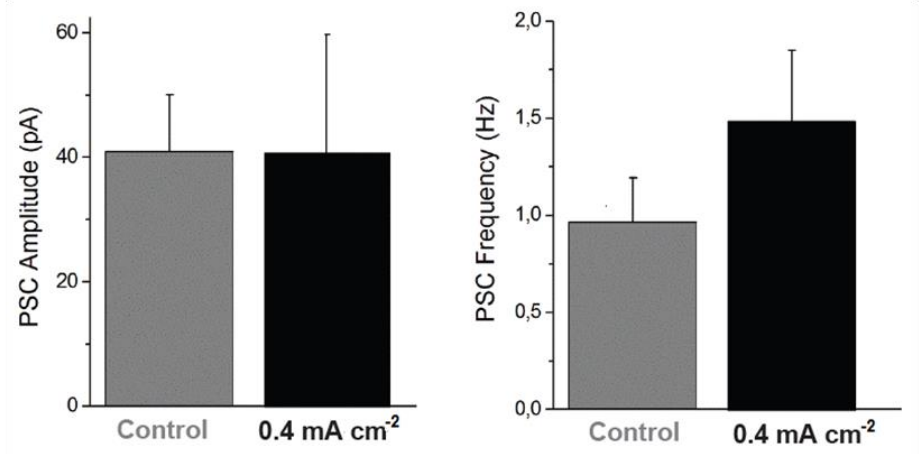

D)
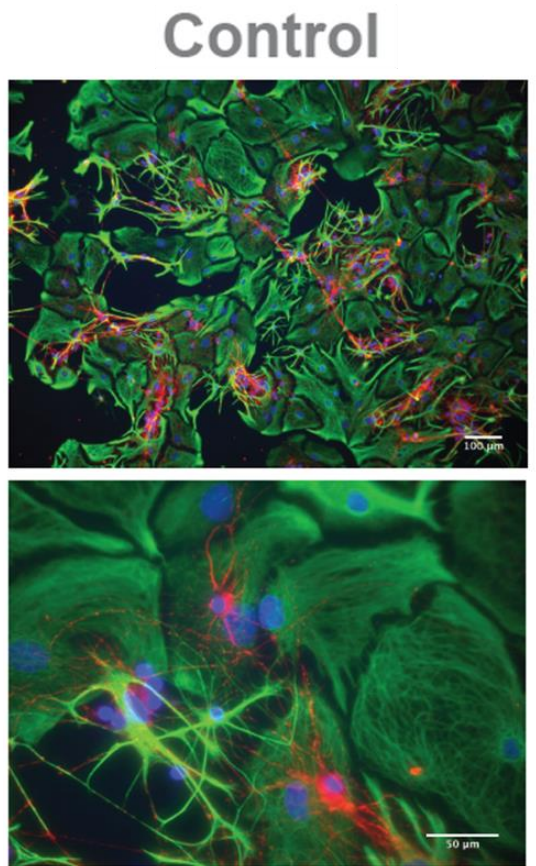

\section{$0.4 \mathrm{~mA} \mathrm{~cm}^{-2}$}
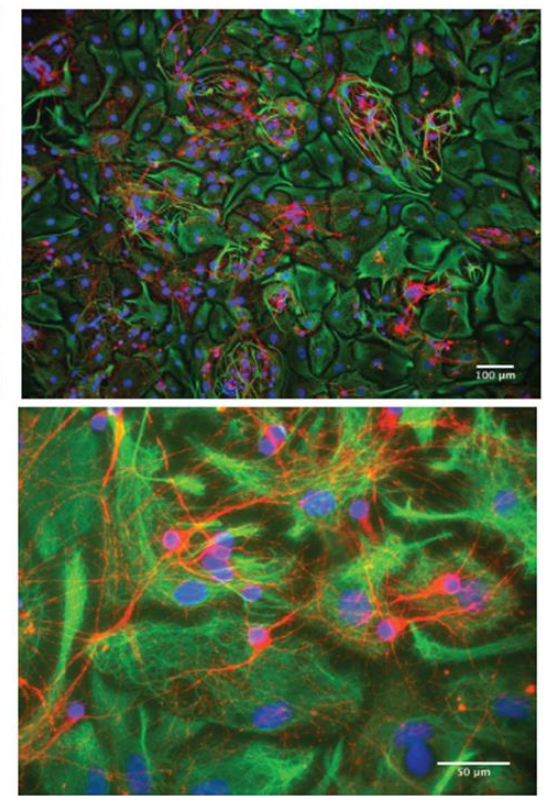

C)
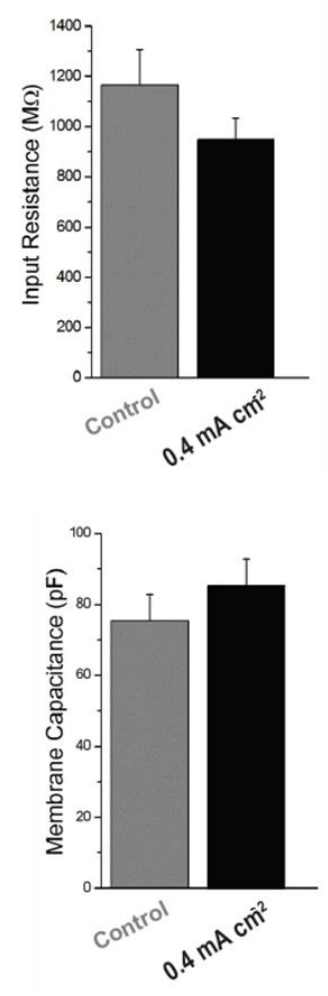

E)

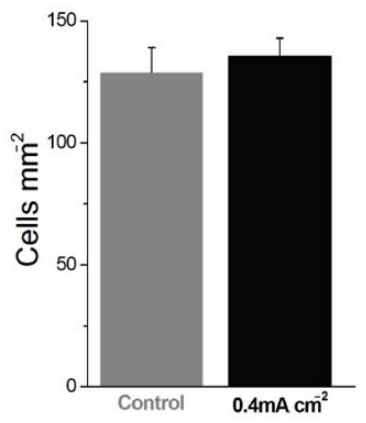

Figure 6. Synaptic network formation on anodized film formed at a current density of $0.4 \mathrm{~mA}$ $\mathrm{cm}^{-2}$. A. Left, current tracings from two sample neurons (in grey control and in black anodized film) showing heterogeneous post-synaptic currents (PSCs; inward deflections) recorded at a holding potential of $-56 \mathrm{mV}$. Right, Superimposed traces show isolated PSCs recorded from Control (top; the average is superimposed in grey) and $0.4 \mathrm{~mA} \mathrm{~cm}^{-2}$ (bottom; the average is superimposed in black) neurons. Bar plots in B. summarize PSC amplitude 


\section{WILEY-VCH}

(left) and PSC frequency (right) values. Although not statistically significant, on anodized films PSC frequency was slightly higher $(0.96 \pm 0.65 \mathrm{~Hz}$ in controls and $1.48 \pm 0.97 \mathrm{~Hz}$ in anodized films, $n=8$ and $n=7$, respectively), while the average values for PSC amplitude were similar (40.8 $\pm 25.9 \mathrm{pA}$ controls and $40.5 \pm 50.7 \mathrm{pA}$ in anodized films). C. Bar plots summarize the values measured for the input resistance (top, $1195 \pm 368 \mathrm{M} \Omega$ controls and $946 \pm 229 \mathrm{M} \Omega$ anodized films) and membrane capacitance (bottom, $75 \pm 20 \mathrm{pF}$ controls and $85 \pm 19 \mathrm{pF}$ anodized film). D. Fluorescent micrographs of immune-labelled cultures, control (left) and anodized films (right), at low (top panels, objective 10x) and high (bottom panels objective 40x) magnifications. Neurons are visualized by anti $\beta$-tubulin III, in red, glial cells by anti-GFAP, in green and nuclei are visualized by Hoeschst, in blue. The plots in E. summarize neuronal (left) and glial (right) densities in all conditions.

Table 1. Physical properties of anodized ITO films formed with different deposition currents. Values of experimental thickness and mean particle diameter of pristine and anodized films formed with $0.4 \mathrm{~mA} \mathrm{~cm}^{-2}, 4 \mathrm{~mA} \mathrm{~cm}{ }^{-2}$ and $43 \mathrm{~mA} \mathrm{~cm}{ }^{-2}$ current densities over a constant time of 450 seconds. The data represent the mean of 15 measurements for film thickness plus $>200$ measurements for particle diameter. Results are $\pm \mathrm{SD}, \mathrm{n}=3$.

\begin{tabular}{ccc}
\hline ITO Film & $\begin{array}{c}\text { Average Thickness } \\
{[\mathrm{nm}]}\end{array}$ & $\begin{array}{c}\text { Mean Particle Diameter } \\
{[\mathrm{nm}]}\end{array}$ \\
\hline Pristine ITO & $750 \pm$ & $86 \pm 17$ \\
Anodized at $0.4 \mathrm{~mA} \mathrm{~cm}^{-2}$ & $109.7 \pm 4$ & $89 \pm 26$ \\
Anodized at $4 \mathrm{~mA} \mathrm{~cm}^{-2}$ & $934.5 \pm 35$ & $152 \pm 78$ \\
Anodized at $43 \mathrm{~mA} \mathrm{~cm}^{-2}$ & $937.8 \pm 47$ & $112 \pm 55$ \\
\hline
\end{tabular}

Table 2. XPS Analysis of the elemental composition of the Pristine ITO and Anodized ITO films

\begin{tabular}{ccccc}
\hline ITO Film & \multicolumn{5}{c}{ Atomic Composition } \\
& [n3 & O1s & C1s & Sn3d5 \\
Pristine ITO & 21.00 & 42.17 & 34.62 & 2.21 \\
Anodized at $0.4 \mathrm{~mA} \mathrm{~cm}^{-2}$ & 24.88 & 43.47 & 30.34 & 1.31 \\
Anodized at $4 \mathrm{~mA} \mathrm{~cm}^{-2}$ & 23.45 & 44.53 & 31.52 & 1.16 \\
Anodized at $43 \mathrm{~mA} \mathrm{~cm}^{-2}$ & 22.75 & 49.81 & 26.65 & 0.78 \\
\hline
\end{tabular}

Table 3. Electrochemical characteristics of ITO anodized films. Charge density evaluated from cathodic region of cyclic voltammograms recorded in $50 \mathrm{mM}$ phosphate buffer at $0.1 \mathrm{~V}$ $\mathrm{s}^{-1}$ scan rate (Potential range: $-1 \mathrm{~V}$ to $0.4 \mathrm{~V}$ vs. $\mathrm{Ag} / \mathrm{AgCl}$ ). $\mathrm{E}^{\circ \prime}$ and $\mathrm{i}_{\mathrm{pa}}$ evaluated from voltammograms recorded in $50 \mathrm{mM}$ phosphate buffer containing $2 \mathrm{mM}\left[\mathrm{Ru}\left(\mathrm{NH}_{3}\right)_{6}\right]^{3+}$ at $0.1 \mathrm{~V}$ $\mathrm{s}^{-1}$ scan rate.

\begin{tabular}{ccccc}
\hline ITO Film & $\begin{array}{c}\text { Charge Density } \\
{\left[\mu \mathrm{cm}^{-2}\right]}\end{array}$ & $\begin{array}{l}\mathrm{E}^{\circ} \\
{[\mathrm{V}]}\end{array}$ & $\begin{array}{c}\mathrm{i}_{\mathrm{pa}} \\
{\left[\mathrm{mA} \mathrm{cm}^{-2}\right]}\end{array}$ & $\begin{array}{c}\mathrm{D}_{\mathrm{o}^{2}} \\
{\left[\mathrm{~cm}^{-1}\right]}\end{array}$ \\
\hline Pristine ITO & 49 & -0.13 & 0.62 & $4.62 \times 10^{-6}$ \\
Anodized at $0.4 \mathrm{~mA} \mathrm{~cm}^{-2}$ & 341 & -0.13 & 0.67 & $8.37 \times 10^{-6}$ \\
Anodized at $4 \mathrm{~mA} / \mathrm{cm}^{-2}$ & 15 & -0.14 & 0.02 & $6.92 \times 10^{-9}$ \\
Anodized at $43 \mathrm{~mA} / \mathrm{cm}^{-2}$ & 15 & - & - & - \\
\hline
\end{tabular}




\section{WILEY-VCH}

The anodization of ITO films by varying current densities is investigated as facile method to modify the morphological, electrical and cytocompatibility profiles of the resulting anodized films as neural electrodes. The systematic study elucidates that the current density of $0.4 \mathrm{~mA} \mathrm{~cm} \mathrm{~cm}^{-2}$, results in a well distributed surface morphology, minimum impedance, and support for cell viability and neural network activity.

Keyword indium-tin-oxide, cytocompatibility, neural interfaces, functionalization, electrodes

Catalina Vallejo-Giraldo, Anuradha R. Pallipurath, Niccolò Paolo Pampaloni, John O'Connell, Gemma Orpella-Aceret, Eugenia Pugliese, Alexandre Trotier, Parvaneh Mokarian-Tabari, Justin D. Holmes, Laura Ballerini, Eilís Dowd, Abhay Pandit, Paul Kavanagh* and Manus Jonathan Paul Biggs*

\section{Preparation of Cytocompatible ITO Neuroelectrodes with Enhanced Electrochemical Characteristics Using a Facile Anodic Oxidation Process.}

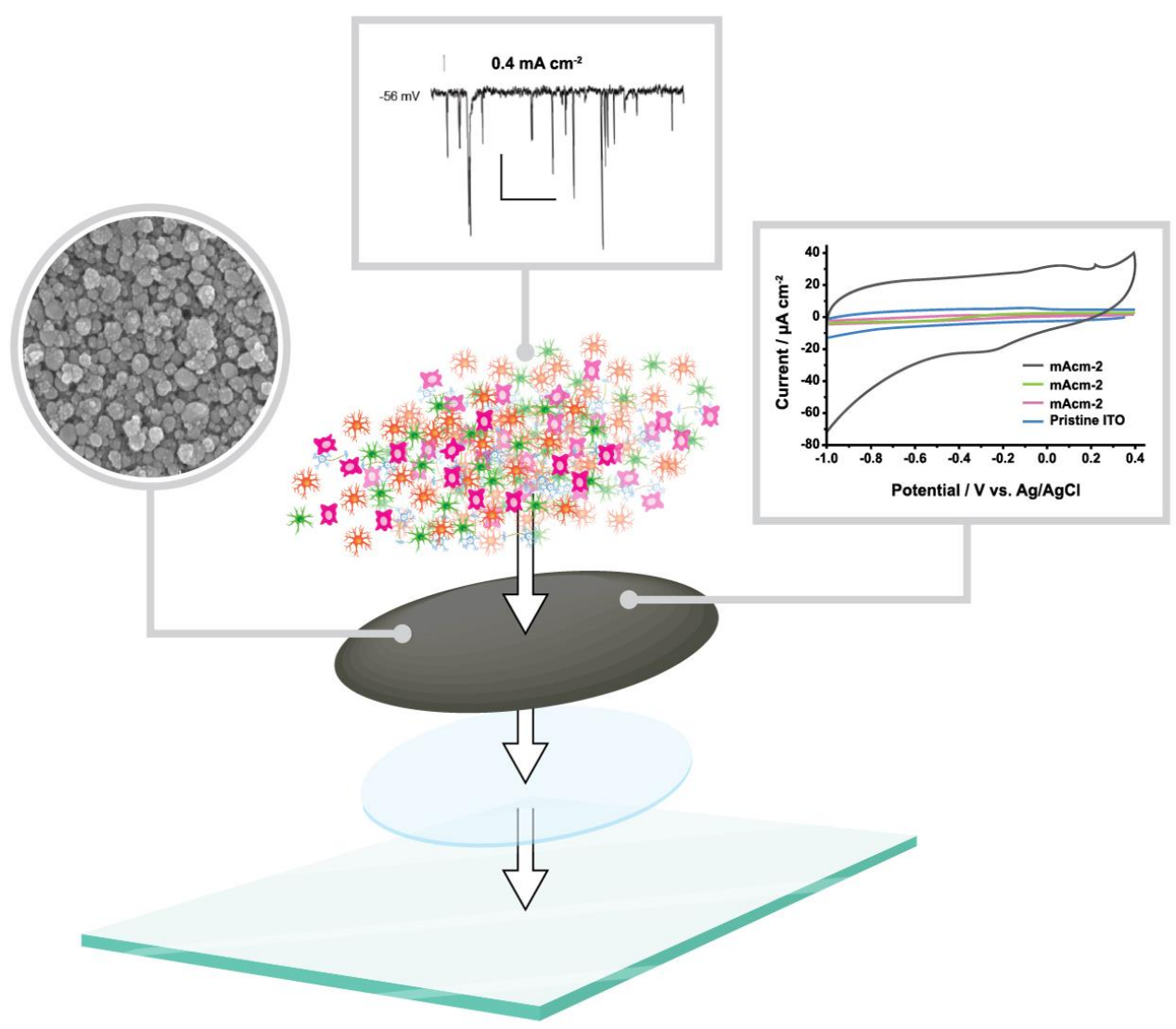


Click here to access/download Supporting Information

Supporting Information-Vallejo-Giraldo et alAFM.docx 